\title{
Brachiopod Gyrosoria Cooper, 1973 - a comparative palaeoecological, stratigraphical and taxonomical study
}

\author{
JAN SKLENÁŘ \& ERIC SIMON
}

\begin{abstract}
Cooper (1973) erected Gyrosoria as a monospecific genus for Terebratulites gracilis von Schlotheim, 1813. G. gracilis from white-chalk facies was studied in detail by Steinich (1965) and its morphological adaptation to the environment was discussed by Surlyk (1972). However, populations of G. gracilis, adapted to a high energy environment remained unnoticed and therefore special attention is paid to them in this paper. "Terebratulina" lata Etheridge, 1881, placed here in the genus Gyrosoria, has often been mentioned within the literature and has been used as a zone fossil for more than a century. However, its morphology and its relation to other reported cancellothyridid species has not been studied in detail since its erection. This paper presents an emended diagnosis of the genus, officially assigns the revised lata species to it and presents a detailed morphological study of the genus. The variability of G. lata, studied here, and compared to that of both, the low- and high-energy-environment forms of G. gracilis, points out a clear evolutionary lineage within the genus. Spicular skeletons have been investigated in some Upper Turonian G. lata shells. Particular attention is given to the shell infrastructure. Moreover this paper shows that the palaeogeographical area of G. lata can now be enlarged but a wider application of this species in biostratigraphy should be refused due to the extension of its stratigraphical range. - Key words: Brachiopoda, Cancellothyridoidea, Upper Cretaceous, environmental adaptation, palaeoecology, shell structure, biostratigraphy.
\end{abstract}

SKLENÁ̌̌, J. \& SIMON, E. 2009. Brachiopod Gyrosoria Cooper, 1973 - a comparative palaeoecological, stratigraphical and taxonomical study. Bulletin of Geosciences 84(3), 437-464 (13 figures, 2 tables). Czech Geological Survey, Prague. ISSN 1214-1119. Manuscript received October 6, 2008; accepted in revised form January 21, 2009; published online September 7, 2009; issued September 11, 2009.

Jan Sklenář, Palaeontological department, National Museum, Václavské náměstí 68, 11579 Praha 1, Czech Republic; jan_sklenar@nm.cz • Eric Simon, Palaeontological department, Royal Belgian Institute of Natural Sciences, rue Vautier 29, 1000 Bruxelles, Belgium; ericsimon98brach@yahoo.fr

The genus Gyrosoria had been erected by Cooper (1973) for Terebratulites gracilis von Schlotheim, 1813, with only a brief diagnosis giving rather general characters as to the shape and the nature of the costellae. Cooper placed this genus into his new subfamily Cricosiinae, demarcated by the presence of a "narrow tube-like loop". This genus was monospecific when created. The purpose of this study is, among other, to check if other small cancellothyridoid species could be included in this genus. At first glance, Terebratulina lata Etheridge, 1881 could be an interesting candidate as is suggested by its general outline and some internal characters such as its loop. This paper proposes for this species, a well documented and careful analysis based on a revised morphological description and on precise palaeoecological study. As T. lata has been collected from numerous European outcrops, a new stratigraphical study has also been realized.

The comparison between $T$. lata and the type species G. gracilis is an important part of this paper and evolutionary trends between these two representatives have been stressed. The discovery of morphological transitional forms in the Turonian of Lenešice, Czech Republic and palaeoecological variations observed in specimens from the Maastrichtian of Altembroeck (Belgium) respectively were arguments used in the search for an evolutionary route for speciation. An interesting remark was stressed by Surlyk (1972), who stated that "stratigraphically slightly older forms of the T. gracilis group have a more biconvex shape". This assertion lead to the study of a possible evolution of the G. gracilis lineage through time and this is one of the aims of this paper.

This paper also aims to check the necessity for emending both the genus diagnosis and the Gyrosoria lata diagnosis. These emendations, if they are made, must be based on morphological observations of a large number of specimens and must be confirmed by statistical analyses. The internal structures must also be investigated using excavation of specimens as serial transverse sections. Consequently, our knowledge of the general distribution of the afore mentioned species will be improved and stratigraphical as well as palaeoecological implications can be drawn. 


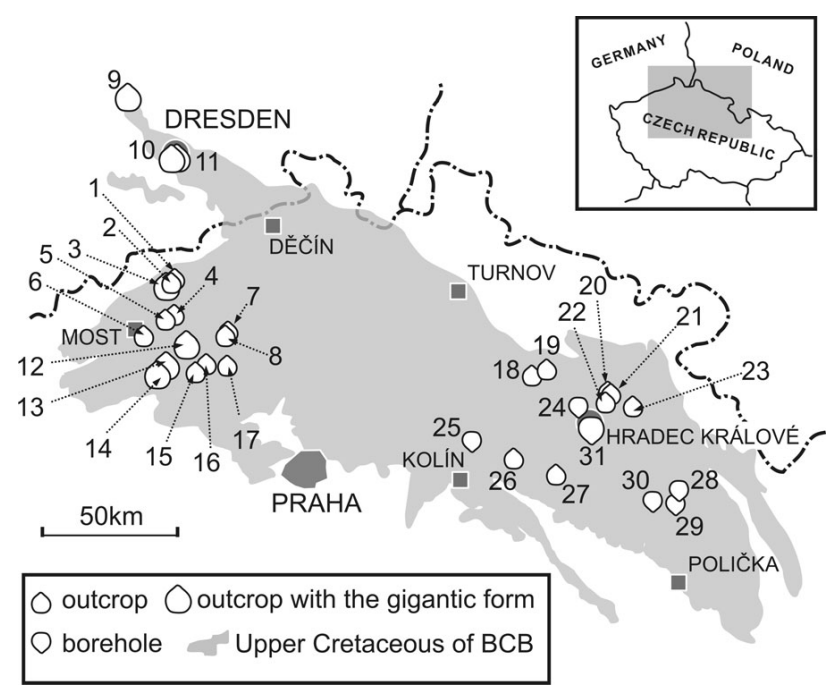

Figure 1. Map of the Bohemian Cretaceous Basin with outcrops and boreholes which yielded the studied specimens of Gyrosoria lata (Etheridge). 1 - Řetenice, 2 - Hudcov, 3 - Lahošt, 4 - Kučlín, 5 - Liběšice, 6 - Bečov, 7 - Č́ž́kovice, 8 - Úpohlavy, 9 - Weinböhla, 10 - Plauen, 11 - Strehlen, 12 - Třtěno, 13 - Lenešice, 14 - Bílé Horky, 15 - Kystra, 16 - Koštice, 17 - Poplze, 18 - Holovousy, 19 - Dachovy, 20 - Vlkov near Smiřice, 21 - Smržov, 22 - Čibuz, 23 - Městec near Opočno, 24 - Všestary, 25 - Dlouhopolsko, 26 - Uhlî̌ská Lhota, 27 - Valy near Přelouč, 28 - Džbánovec, 29 - Dolní Sloupnice, 30 - Džbánov near Vysoké Mýto, 31 - Hradec Králové. Dash-and-dot line is for the state borders, grey for the Upper Cretaceous sediments of the basin. For details see material and methods chapter.

\section{Material}

Maps are given only for the two essential areas, where material has been collected recently - the Bohemian Cretaceous Basin (BCB, Fig. 1) and Maastrichtian localities (Fig. 3).

Abbreviations. - APB - Anglo-Paris Basin, BCB - Bohemian Cretaceous Basin, BGS - British Geological Survey collections (Keyworth), CGS - Česká geologická služba (Prague), FSCU - Faculty of Science, Charles University (Prague), GBA - Geologische Bundesanstalt (Wien), IRScNB - Institut royal des Sciences naturelles de Belgique (Brussels), MEB - Museum of Eastern Bohemia (Hradec Králové), MNHN - Muséum National d'Histoire Naturelle (Paris), NHM - Natural History Museum (London), NHMM - Natuurhistorisch Museum Maastricht (Maastricht), NHMW - Naturhistorisches Museum (Wien), NM - Národní muzeum (Prague), SNSD - Staatliche Naturhistorische Sammlungen Dresden (Dresden).

\section{Gyrosoria lata material}

The studied specimens of G. lata come from three different areas. The most abundant material originates from the Bohemian Cretaceous Basin followed by the material from the Anglo-Paris Basin (APB) - English part of the basin and auxiliary material from the Mons Basin.
Bohemian Cretaceous Basin. - The majority of the material is available in collections of NM, Prague, other material has been studied in MEB, NHMW, GBA and SNSD collections. Number of the specimens is given for the most important sets only. The number in parentheses is a serial number accordant with the map (Fig. 1).

Material: (8) Úpohlavy (Lovosice): about 1550 specimens, mostly complete but disarticulated specimens have been preserved in detrictic accumulations; NM - d 48/2006; (13) Lenešice (Louny): articulated shells from the brickyard (134 specimens, NM - d 31/2008, coll. Nekvasilová); (18) Holovousy (Jičín): 756 specimens (684 complete articulated shells, 46 dorsal, 22 ventral valves).

More than 1000 specimens including borehole-samples come from 28 other localities (see Fig. 1 and the following list): (1) Řetenice (Teplice; = Setenz), Upper Turonian, NM - d 153/2004, d 44/2006; (2) Hudcov (Teplice; = Hundorf), Upper Turonian, NHMW - 1886-XXVI-56; (3) Lahošt (Teplice; = Loosch), ?Middle Turonian, leg. Dvořák, NM - d 19/2007; (4) Kučlín (Teplice; = Kutschlin), Upper Turonian, leg. Vodrážka, Sklenář, NM - d 14/2007; (5) Liběšice (Most), Upper Turonian, leg. Vodrážka, Sklenář, NM - d 48/2006; (6) Bečov (Most; = Hochpetsch), ?Upper Turonian, NM - 36675; (7) Čížkovice (Lovosice), Upper Turonian, leg. Nekvasilová, NM - d 167/2004; (9) Weinböhla (Dresden), Upper Turonian, GBA (no number) and SNSD - SaK 8457; (10) Plauen (Dresden), Upper Turonian, SNSD (no number); (11) Strehlen (Dresden), Upper Turonian, GBA (no number) and SNSD - SaK 9340, SaK 9964; (12) Třtěno (Louny; = Křtěnov, Kröndorf), Upper Turonian, NM - 36675; (13) Lenešice (Louny): in addition to the brickyard a locality by a yard "Zájezd" (= "Zagesthof”), Upper Turonian, GBA and NM - d 167/2004 (leg. Nekvasilová) and an outcrop "Poustka", Upper Turonian, leg. Nekvasilová, NM - d 167/2004; (14) Bílé Horky (Louny; = Weisser Berg bei Laun), Middle Turonian, leg. Sklenář, NM - d 43/2008; (15) Kystra (Louny), Upper Turonian, leg. Sklenář, NM - d 38/2006 and leg. Nekvasilová, NM - d 167/2004; (16) Koštice (Louny; = Koschtitz), Upper Turonian, leg. Nekvasilová, Houša, Čepek, NM - d 229/2007, d 187/2007, NM - 36675; (17) Poplze near Libochovice (Litoměřice; = Poplsy), Upper Turonian, NM - 36675; (19) Dachovy (Jičín), ?Middle Turonian, leg. Nekvasilová, NM - d 167/2004; (20) Vlkov near Smiřice (Náchod), Turonian, MEB - 71125, 71137; (21) Smržov - "Bílý Kopec" (Hradec Králové), coll. Hlaváč, MEB - 71130; (22) Čibuz (Hradec Králové), Turonian, MEB - 71128; (23) Městec near Opočno (Rychnov nad Kněžnou), Turonian, MEB 71259; (24) Všestary (Hradec Králové), borehole VY-1, 340.7 m, ?Upper Turonian, leg. Müller, NM - d 47/2008; (25) Dlouhopolsko (Nymburk), borehole KN-2, Turonian, NM - d 47/2008; (26) Uhlírská Lhota - Božec, "Datel" 
wood (Kolín), Turonian, coll. Jahn, MEB - 71053; (27) Valy near Přelouč (Pardubice), Turonian, MEB - 71053; (28) Džbánovec (Ústí n. Orlicí), borehole Lo-19, 68.9 m, ?Middle Turonian, leg. Štaffen, NM - d 153/2005; (29) Dolní Sloupnice (Ústí n. Orlicí), borehole Lo-11, Upper Turonian, don. Čech, NM - d 47/2008; (30) Džbánov near Vysoké Mýto (Ústí nad Orlicí), borehole Lo-16, 74.25, 74.3 m, Upper Turonian, don. Čech, NM - d 47/2008; (31) Hradec Králové, borehole HK-184, 251.5 m, Turonian, don. Čech, NM - d 47/2008.

Comments: The overwhelming majority of the material studied comes from hemipelagic facies of the Upper Turonian age. There are also some problematic collections of rather uncertain age, but probably being Middle Turonian (e.g., Holovousy or Lahošt material) and only one collection comes from rock layers with this age confirmed (Bílé Horky). All the occurrences are bound to distal marl sedimentation containing a lower terrestrial component. The species is never primarily abundant in limestone with a higher carbonate content and never autochtonously occurs in coarser siliciclastic sediments. The abundance of G. lata is often controlled directly by the oscillation of the carbonate content or terrestrial input (Čech 1995). The leading localities for this study are Úpohlavy near Lovosice and Lenešice near Louny.

Úpohlavy working quarry offers one of the main sections through the Upper Turonian hemipelagic sequences. This section through the uppermost part of the Jizera Formation and lower part of the Teplice Formation has been studied in detail during the last two decades and much palaeontological and biostratigraphical, as well as sedimentological data has been acquired (e.g., Wiese et al. 2004, Žítt \& Vodrážka 2008). G. lata has been found in two distinct high-abundance-bands here - the first in lithounit $\mathrm{Xa}$, the second within the lower part of $\mathrm{Xb} \beta$ unit (Krutský et al. 1975, Wiese et al. 2004). The character of these $G$. lata oryctocoenoses is different. The first consists of prevailingly disarticulated, abraded shells, which are indicative of a taphonomic enrichment and probably derived from the unit IX marls (Macák 1963). As already noted by Schloenbach (1868) G. lata remains are one of the main components in planar patch-like accumulations of fine detritus of mollusc and ostracod shells, vertebrate remains and large benthic foraminifera. These patches described by Frič (1889) as "Koschtitzer Platten" (Koštice plates), are considerably variable in density and size and are typical for the base of the Teplice Formation (S. neptuni Zone) in the Ohře region, e.g., Koštice and Kystra. They are also less frequently found in the eastern part of the basin (Uhliřská Lhota and Valy, Fig. 1). The brachiopod assemblage of this lower high-abundance band is almost monospecific - beside G. lata only very rare specimens of Terebratulina striatula) have been found in Úpohlavy. The second
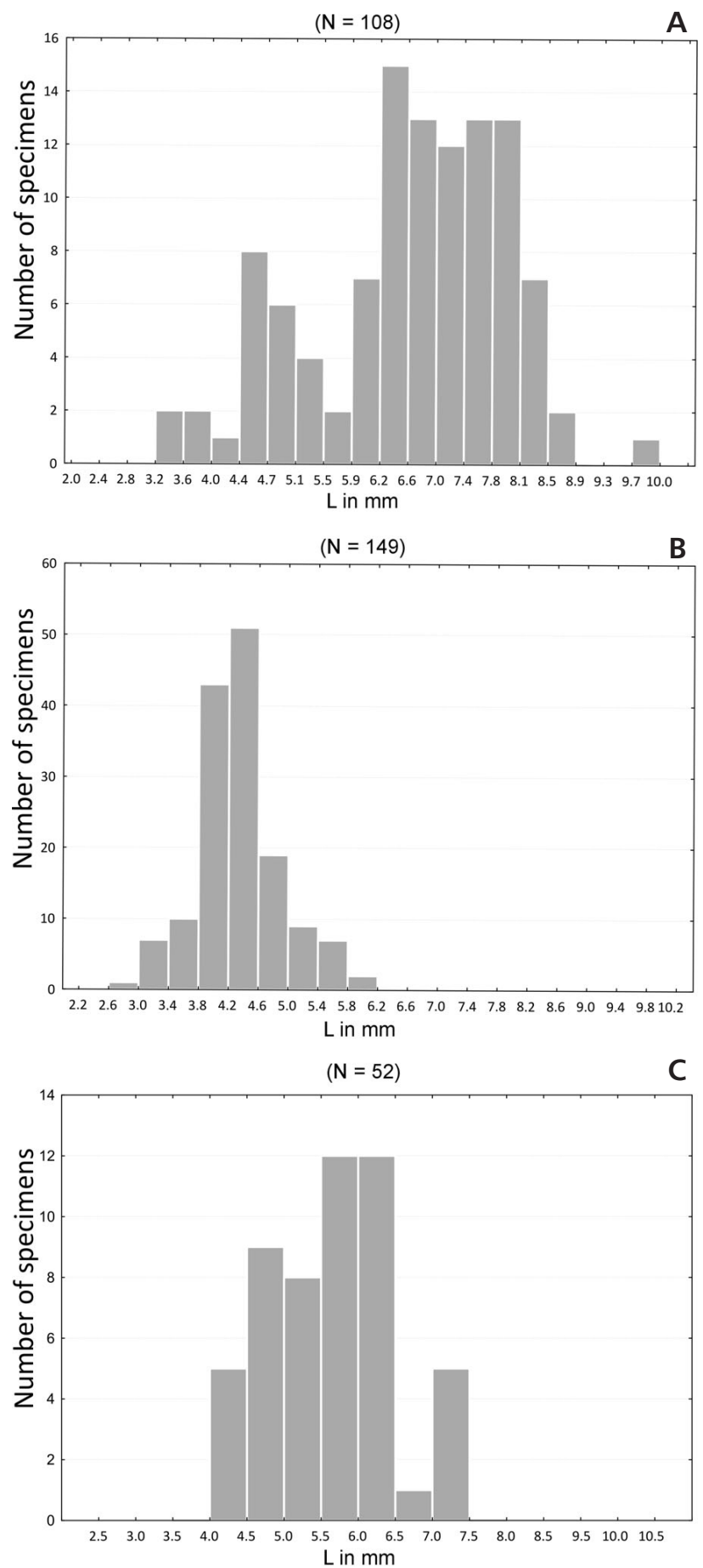

Figure 2. Histograms of three Gyrosoria lata (Etheridge) oryctocoenoses. - A - a histogram showing structure of the Lenešice oryctocoenosis [Bohemian Cretaceous Basin (BCB), Upper Turonian, Teplice Formation, unit $\mathrm{Xb}$ ] including gigantic specimens. The set is slightly bimodal. $\bullet \mathrm{B}-\mathrm{a}$ histogram showing structure of an oryctocoenosis from Úpohlavy (BCB, Upper Turonian, Teplice Formation, unit $\mathrm{Xb} \beta$ ), common form of G. lata from $\mathrm{BCB}$. A slight convergence in shape with the left side of the Lenešice histogram (A) is apparent. $\bullet \mathrm{C}$ - length distribution within oryctocoenosis from the White Chalk of Dover (Anglo-Paris Basin, Middle? Turonian, Middle Chalk). The limit of the Gauss distribution is situated at values for the slight discretion apparent in the Lenešice histogram (A). 
high-abundance band - in $\mathrm{Xb} \beta$ - consists mostly of articulated, well preserved shells and presents a population preserved near to the living area. G. lata was accompanied by a multifarious brachiopod assemblage here with typical inhabitants of softground [(Gibbithyris semiglobosa, Woodwardirhynchia cuneiformis, Isocrania sp.) and rather rare kingenids with a strongly convex ventral valve] accompanied by $T$. striatula, "Cretirhynchia" minor and Orbirhynchia reedensis (Etheridge, 1881). Occurrences of $G$. lata inbetween these two levels are rare and no appearance has been recorded above $\mathrm{Xb} \beta$ [above I. labiatoidiformis/striatoconcentricus Zone (Wiese et al. 2004)].

An abandoned brickyard NW from Lenešice near Louny is the second essential locality for $G$. lata research. An oryctocoenosis occurring here in the Upper Turonian sediments (Teplice Formation, Xb unit, Váně 1964) consists not only of the common "small" form found within the BCB (Fig. 2), but also of giant specimens (up to $10 \mathrm{~mm}$ ) showing finer costellae (Fig. 8A, C; Table 1) and usually slightly more flattened dorsal valves. Similar specimens also occurred at the Lahošt (Teplice district) locality (NM - d 19/2007) or in Strehlen (SaK 9964) and Weinböhla, both in Dresden area (SNSD, Fig. 1). Areas containing this gigantic form seem to be rather restricted to the western part of the basin (there is only one exception, a sample from the borehole HK-184). Its distribution always coincides with the presence of the common "small" form with exception of the Lahošt locality, where only the giant specimens have been recorded. This gigantic form of G. lata ("T. rigida") was recorded for the first time by Schloenbach (1868). He also mentioned this very locality as typical for the form. Schloenbach considered this form to be bound to stratigraphically higher units whereas he considered the common "small" form to be typical for the lower ones. Such an observation could not be confirmed as the giant form has been recorded from the Upper Turonian (Lenešice, Strehlen) as well as the Middle Turonian sediments (Bílé Horky) and seems to be stratigraphically independent. The same has been observed for the common form.

The geological situation at the Lenešice locality is rather complicated due to tectonic dislocation. The part where the studied material obtained by $\mathrm{O}$. Nekvasilová comes from is a block of whitish marls bordered from North and South by a bifurcated fault (Váně 1964). A "typical fauna of Xb" is reported by this author, but no more detailed information is given. Outcrops at this part of the locality had been forested during the 1970's and are not accessible anymore.

The English part of Anglo-Paris Basin. - All material comes from the Chalk facies of the Southern Province (with the exception of the Boswell Farm locality). The majority of the English (APB) material has been studied in the NHM collections, part is also stored in the collections of the NM, Prague.
Material: White Cliff, Hooken (South Devon coast): 55 complete isolated shells, and complete specimens in samples of accumulations from the same locality, coll. Rowe, NHM B-19318-32; Beer Head (Devon), Middle Chalk, 1 complete specimen and isolated valves as well as articulated specimens on the surface of a sample with detritic accumulation, coll. Nekvasilová, NM - T 3307; Borstal pit near Rochester (Kent), isolated valves as well as articulated specimens on the surface of a sample with detritic accumulation, coll. Rowe, NHM - B-79317; Folkestone (Kent), Middle Chalk, 5 complete specimens, NHM - B-43255-59 (coll. Brown); Warren near Capel, Folkestone (Kent), 2 complete specimens, NM T 3308-09 (coll. Nekvasilová); Dover (Kent), Middle Chalk, 3 complete specimens, coll. Nekvasilová, NM - T 3305-06; Froxfield, Petersfield (Hampshire), Middle Chalk, 2 complete specimens, coll. Nekvasilová, NM - T 3310-11; Boswell Farm, Louth (Lincolnshire), Upper Chalk, 3 complete specimens, coll. Farmey, NHM - B-55235.

Comments: Specimens from British localities fall within the Middle to Upper Chalk stratigraphical range (i.e. T. lata and $H$. planus zones of classical biostratigraphy). As $G$. lata was used as a main stratigraphical marker for correlation at the time the material was collected, stratigraphical data are rather uniform for all the samples. It is worth mentioning that small accumulations of G. lata specimens and their isolated valves occur at some of the localities (Borstal pit, Rochester). Such accumulations also contain a variable component of small echinoid and tiny-mollusc detritus with large foraminifers. These patches resemble very closely the accumulations often found in some of the BCB localities, where also ostracods, fragments of inoceramid shells and fish-like-vertebrate remains are usually involved. This phenomenon has been interpreted within the BCB as current created structures (Macák 1963) with a probable wave-base reworking influence, or even a tempestitic origin possibility (Wiese et al. 2004). Accumulations from White Cliff, Hooken resembling this phenomenon are probably of another origin and seem to be remains of assemblages preserved in situ, as most of the individuals are orientated in the sediment and complete.

Mons Basin (APB). - All observed Belgian material (more than 100 specimens) is housed within the IRScNB collections.

Material: Autreppe and Tournai, "Lower Turonian" ("Marne Grise"), IRScNB - I.G. 10511; St. Vaast-Maisières, Upper Turonian ("Craie de Maisières"), IRScNB I.G. 5496; Chercq, Upper Turonian ("Diéves et Fortes Toises"), IRScNB (number unknown); Montigniessur-Roc, "Lower Turonian" ("Marne Grise"), coll. Quiévrain, IRScNB - I.G. 4919; Perwelz, "Lower Turonian" ("Marne Grise"), IRScNB - I.G. 10511. 
Comments: The stratigraphical rank of the Belgian material studied, is in many cases rather disputable. A significant part of the specimens stored in this collection was originally assigned as Lower Turonian (Autreppe, Montignies-surRoc and Perwelz). However, there is a strong possibility that the material comes from higher positions in the section (J. Herman, personal communication). In the case of the Autreppe locality G. lata used to be found right below the Turonian/Coniacian boundary (J. Herman, personal communication). Specimens from St.Vaast-Maisières are reported to come from "Craie de Maisières" on the respective label (IRScNB). This unit is of the formation rank now Maisières Chalk Formation - which was supposed originally to be Upper Turonian and more recently revised as Coniacian (Robaszynski et al. 2001). In Chercq G. lata is found in marls above the Lower Turonian bed together with redeposited $A c$ tinocamax plenus. There is a hiatus between the latter and the first unit (J. Herman, personal communication). Some of the samples have been preserved in glauconitic sandstones (Maisières, Montignies-sur-Roc) in which they were probably redeposited from marls. There were no gigantic specimens found in the observed material from the Mons Basin.

\section{Gyrosoria gracilis material}

The G. gracilis material comes from different outcrops situated in north-east Belgium near the Netherlands-Belgium border and in the Maastricht area, southern Limburg, The Netherlands (see Fig. 3).

Dutch-Belgian extended type area of the Maastrichtian Stage.-Material: Altembroeck: 25 specimens, 12 small and 5 juveniles from level $\mathrm{Bm} 2,8$ larger specimens, glauconite-rich bed Gc1, upper part of the section. (IRScNB - I.G. 28071 (leg. "Viljen Werkgroep") and IRScNB - MI-11060 (coll. Bosquet).

Comments: These specimens are not numerous but they are of importance in view of the fact that they are representatives of a high-energy environment. This is confirmed by the state of preservation of their shells and by their association with other brachiopod species, such as Neoliothyrina obesa.

In 1994, long-term fieldwork was carried out by members of the "Vijlen Werkgroep" (NHMM) at Altembroeck ('s Gravenvoeren, province of Limburg, NE Belgium), which yielded numerous fossils. The belemnite fauna suggested a late Early Maastrichtian age for this material and part of the section could be correlated with the middle $B$. sumensis Zone (Jagt et al. 1995). In 1997, Keutgen pointed out the presence of Belemnella (B.) cf. praearkhangelskii and discussed the Altembroeck section in more detail. Level Bm2 (belemnite-rich bed, Jagt et al. 1995, p. 19) has been correlated with the middle $B$. sumensis Zone. Keutgen (1997, p. 346) noted that belemnites from the upper part of

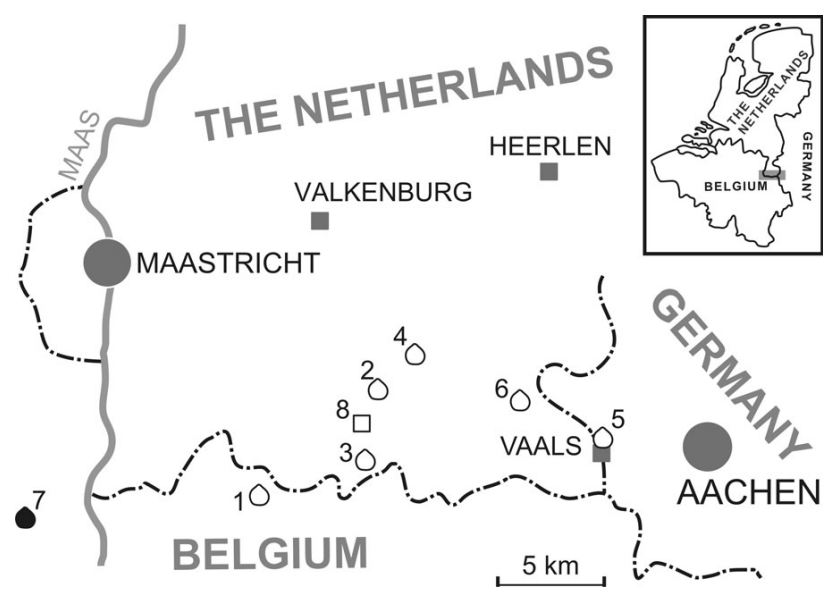

Figure 3. Map of the localities which yielded specimens of Gyrosoria gracilis (von Schlotheim) figured or mentioned in this paper. 1 - Altembroeck 2 - Pesaken, 3 - Slenaken, 4 - Gulpen, 5 - Schneeberg (Vaals), 6 - Vijlen, 7 - CPL quarry Hallembaye, 8 - Beutenaken (no G. gracilis found, but locality mentioned in the text). Black-filled locality-pictogram is for low-energy environment. State borders marked with the dash-anddot line. For details see material and methods chapter.

the section, i.e. between the glauconite-rich bed Gc1 (see Jagt et al. 1995) and the belemnite-rich bed Bm4, appear to have been reworked from underlying deposits (Keutgen $e t$ $a l .$, in press).

Material: Pesaken, Slenaken, Gulpen and Vaals (Schneeberg), Lower Maastrichtian, 192 specimens. Vaals (outcrop not precisely indicated): 39 complete specimens, 6 dorsal valves and 4 ventral valves; Vaals, from the Schneeberg: 19 complete specimens and 19 fragments; Slenaken: 18 complete specimens and 13 fragments; Slenaken/Pesaken and Gulpen (lacking precise data): 70 complete specimens, 2 ventral valves and 1 fragment. Material housed in the IRScNB (I.G. 4285).

Comments: This material is relatively well preserved and presents a very wide variation in morphological characters. Most of the shells have a drop-shaped outline, a slightly convex or flat dorsal valve with a moderately or poorly developed beak. However, some specimens have a longer curved beak associated with a strongly convex ventral valve, a character set found more commonly in representatives collected from white chalk.

During the $19^{\text {th }}$ century, Bosquet collected numerous brachiopods from temporary outcrops situated along the Gulp River, all localities situated in southern Limburg. He also collected in the neighbourhood of Vaals from outcrops situated at the Schneeberg. This rich brachiopod fauna consists mainly of numerous Neoliothyrina obesa and Gisilina gisii. Terebratulina chrysalis, Nerthebrochus ovalis and Mosaethyris felderi are also well represented. All these species, and G. gisii in particular, suggest a late Early 
Maastrichtian age and a possible correlation with the $B$. obtusa/B. sumensis Zones. On the basis of the belemnite fauna, Keutgen \& Van der Tuuk (1991) established an upper B. sumensis Zone age for boulders of Vijlen Chalk collected in fields on the Schneeberg at Vaals. However, the disused Habets quarry at Beutenaken (Fig. 3), is the stratotype of the Beutenaken Chalk Member, which is older than the Vijlen Chalk Member, as it is supposed to be correlated with part of the B. obtusa Zone (Keutgen \& Van der Tuuk 1991). For these reasons only, an approximate stratigraphical position can be considered for this material. It is suggested that this material is from the (?) $B$. sumensis/B. obtusa zones.

Material: Neighbourhood of Vijlen, ?Lower Maastrichtian, 17 specimens, coll. Felder, NHMM (no number).

Comments: These specimens are fully adult, some of them being ventribiconvex or plano-convex (similar to the specimens from Altembroeck), others being concavo-convex (similar to the specimens of Hallembaye).

Material from the Felder Collection, collected from the area of Vijlen, southern Limburg, The Netherlands (Fig. 3) has also been used for this study. Although no precise outcrop is mentioned for this material, it is assumed that these specimens were collected from the Vijlen Member and they can be assigned to the B. sumensis/B. obtusa Zone.

Material: Hallembaye, Lower Maastrichtian, 6 specimens, coll. Jagt, NHMM - JJ-4924.

Comments: Material collected from the disused "Ciments Portland Liégeois" quarry (CPL quarry, Fig. 3) at Hallembaye, province of Liège, Belgium, is illustrated in this study for comparison. The Gulpen Formation has maximum development in this quarry and the Zeven Wegen, Vijlen, Lixhe 1-3 and Lanaye members are exposed. Only the lowest 6 metres of the Vijlen Member are taken into account here; these have been correlated with the earliest Late Maastrichtian, B. junior Zone (Christensen \& Schmid 1987, Dhondt \& Jagt 1987, Jagt \& Michels 1990, Keutgen et al. in press). This a white chalk facies and the brachiopod fauna consists of numerous $G$. gracilis associated with the rhynchonellid Homaletarhynchia undulata maastrichtiensis and Magas chitoniformis. These specimens of Gyrosoria are identical to those collected from the Maastrichtian white chalk from northern Germany and Denmark.

\section{Methods}

SEM photos of the ultrastructure and spicular skeleton were obtained with JEOL-6380LV, FSCU, Prague and
ESEM XL30, IRScNB, Brussels. Specimens to be photographed were coated with ammonium chloride.

179 specimens of Gyrosoria lata from the Bohemian and English localities and 83 specimens of Gyrosoria gracilis were measured (Table 42). The minimal, maximal and mean value of the measurements are given for the different samples investigated and for the whole set of measurements. The length $(\mathrm{L})$, the width $(\mathrm{W})$, the thickness $(\mathrm{T})$, the apical angle $(\beta)$, the angle of the hinge line $(\gamma)$ of each specimen and the number of costellae ornamenting the surface of the dorsal valve have been taken into account. The ratios of length to width $(\mathrm{L} / \mathrm{W})$, thickness to width (T/W) and number of costellae to width (nbr.cost./W) were calculated. The measurement of the angles is often a critical operation. For obtaining the best measurements, we scanned the specimens of $G$. gracilis from a dorsal view and the angles were always determined in the same way from the photographs. As a lot of specimens of $G$. lata have been studied without any possibility of scanning, all measured specimens had been carefully oriented with the dorsal valve parallel to the lens and photos have been taken using the same focal length and camera.

The internal characters of $G$. lata were investigated in serial sections from nine specimens (all specimens included in the numbers cited above): two from Úpohlavy near Lovosice (BCB, NM - d 36/2008, Fig. 4A, B), two from Lenešice near Louny (BCB, NM - d 34/2008), four from Holovousy (BCB, NM - d 35/2008) and one from Dover (APB, NM - d 33/2008, Fig. 5).

For serial sections of G. lata, a hand-powered Croft machine (Croft 1950) has been used. Material was cast in epoxy resin, orientated in a way conforming to the recommendations of Sandy (1986) and ground with a $0.05 \mathrm{~mm}$ step using abrasive paper of 600, 800 and 2000 fractions. This method is suitable for very precise grinding of several specimens at a time. Transverse serial sections of the G. gracilis specimen (IRScNB - MI-11060, Fig. 10A, B) were made using the method proposed by Ager (1965) at distances of $0.1 \mathrm{~mm}$. Cellulose acetate peels were taken following the method described by Sternberg \& Belding (1942). Peels of the serial sections are preserved in the IRScNB collections. Orientation of all the figured transverse sections (ventral valve down) was selected for easy comparison with Steinich's (1965) illustrations.

For cleaning an ultrasonic bath has been used. Furthermore, a new sulphuric acid preparation method (Vodrážka 2009) was employed for part of the G. lata material. In addition the usual means of mechanical cleaning were employed (steel needle, brush etc.), as well as detailed cleaning with flexible interdental brushes. In some cases, diluted $\mathrm{HCl}(1 \%)$ was used for separating cemented grains from the matrix. This acid solution was applied to specific zones with a small paint-brush or with a thin injection needle. Water was alternately used for rinsing the treated zone. 
Any contact between acid solution and the brachidium was avoided.

Suprafamilial classification follows Williams et al. (1996) whereas the superfamilial classification follows Williams et al. (2000). The description of the loop structure follows Lee et al. (2006).

\section{Systematic section}

Order Terebratulida Waagen, 1883

Suborder Terebratulidina Waagen, 1883

Superfamily Cancellothyridoidea Thomson, 1926

Family Cancellothyrididae Thomson, 1926

Subfamily Cricosiinae Cooper, 1973

\section{Genus Gyrosoria Cooper, 1973}

Type species. - Terebratulites gracilis von Schlotheim, 1813 by original designation.

Emended diagnosis. - Small to medium-sized, with a drop-shaped to subcircular outline, ventri-biconvex to planoconvex and even concavo-convex. Costellae numerous, fine to strong, granulate or beaded. Beak short, erect to curved, foramen small, deltidial plates disjunct, extended, adjacent to dorsal valve margin. Teeth strong, cardinalia narrow, socket ridges stout, cardinal process small, supported by short ridge, crura thick, oblique, projecting ventrally, supporting a narrow tube-like loop.

Remarks. - This diagnosis emendation is based on the latest one given in Lee et al. (2006). New observations on the variability in type species representatives and their morphological response to the environment have also been taken into account. Differences between this and the former diagnosis concern the lateral profile (originally: "planoconvex"), character of the costellae ("strong") and shape of the beak ("incurved"). Within the new description of internal characters is that the crura are "ventrally projecting". The authors avoided using the pedicle collar as a genus character as its extent is very variable and multiple serial sections proved that it is missing in some specimens of the genus.

The genus Gyrosoria was created by Cooper (1973) as a member of his new subfamily Cricosiinae characterised by the presence of a "narrow tube-like loop". To the subfamily Cricosiinae Cooper (1973) attributed two genera erected by himself, Cricosia and Gyrosoria, and one genus created by Smirnova (1966), Cruralina. These three genera are difficult to distinguish, as they show very similar features. While Cricosia had been confidently demarcated from Gyrosoria due to its gentler cardinalia, larger foramen, deltidial plates position and finer ribs, Cruralina had been considered to be problematic.
Smirnova (1966) selected Barremian C. cruralinica Smirnova, 1966 as a type species, but she (see Cooper 1973) did not figure any serial sections. Smirnova (1966, fig. 1, 1972, fig. 23) figured only an internal reconstruction of internalia based on a non-figured specimen without any further explanation of the drawing's origin. The shape of the internal characters as shown by this reconstruction, seemed unclear to Cooper, but was later confirmed for the genus by Nekvasilová (1978). This author published photos and a drawn reconstruction of the brachidium of $C$. strambergensis from the Lower Cretaceous of Stramberk (Czech Republic), both showing a typical "hinge-platelike" ventrally concave structure supporting anterior terminations of short crura. This is a significant generic character, which unfortunately had not been mentioned in the original description of Smirnova's type species, although noted in the genus description. There were two more species created and inserted by Smirnova (1966) into the new genus: $C$. belbekensis Smirnova and C. rotunda Smirnova, reported to be Hauterivian and Aptian respectively. These are of great importance for the genus definition as Smirnova produced two series of sections for the first one $(1966,1972)$ and one for the latter species (1966). These serial sections show internal characters very similar to those of the genus Gyrosoria, but all of them show more or less the "hingeplate-like" structures described also by Nekvasilová (1978). These features show a high variability in the extent of their development (e.g., in C. belbekensis this structure is hardly distinguishable). This, together with their relative stratigraphical position allows us to presume an ancestor of Gyrosoria within the range of the Cruralina genus.

Cooper's original designation of the genus Gyrosoria was monospecific with $T$. gracilis as type species. The characteristic form of this species from the Maastrichtian Chalk of Rügen area was studied in detail by Steinich (1965) serial sections including (1965, fig. 106). He pointed out the importance of the spicular meshwork of this species. A similar spicular skeleton is also presented for G. lata in this paper.

\section{Gyrosoria lata (Etheridge, 1881)}

Table 1, Figures 4-9A, 12-13

non 1813 Terebratulites gracilis von Schlotheim, p. 113, pl. 3, figs $3 \mathrm{a}, \mathrm{b}$.

non 1829 Terebratula rigida; J. Sowerby \& J. de C. Sowerby, p. 69 , pl. 536, fig. 2.

? 1841 Terebratula ornata N. - Roemer, p. 40, pl. 7, figs 10a-d.

1846 Terebratula gracilis. - Reuss, p. 49, pl. 26, fig. 1.

v 1847 Terebratulina gracilis d'Orb. -d'Orbigny, pp. 61-63.

$v 1849$ Terebratulina gracilis d'Orb. - d'Orbigny, pl. 503, figs $1-6$.

v 1852 Terebratulina subgracilis. - d'Orbigny, p. 169. 
Table 1. Chart of the measurements for selected Gyrosoria lata (Etheridge) oryctocoenoses. For indexes see captions to Table 2.

\begin{tabular}{|c|c|c|c|c|c|c|c|c|}
\hline Localities & & $\underset{m m}{L}$ & $\begin{array}{c}\mathbf{W} \\
\mathbf{m m}\end{array}$ & $\frac{L}{W}$ & $\begin{array}{l}\beta \\
\circ\end{array}$ & $\gamma$ & $\begin{array}{l}\text { Nbr. } \\
\text { cost. }\end{array}$ & $\frac{\text { Nbr.cost. }}{W}$ \\
\hline $\begin{array}{c}\text { Úpohlavy near Lovosice }(\mathrm{Xb} \beta) \text {, Czech } \\
\text { Republic } \\
\text { common BCB population } \\
N=43\end{array}$ & $\begin{array}{l}\min \\
\operatorname{mean} \\
\max \end{array}$ & $\begin{array}{l}3.6 \\
4.4 \\
5.1\end{array}$ & $\begin{array}{l}3.5 \\
4.3 \\
5\end{array}$ & $\begin{array}{l}0.93 \\
1.02 \\
1.36\end{array}$ & $\begin{array}{l}105 \\
116 \\
129\end{array}$ & $\begin{array}{l}158 \\
171 \\
178\end{array}$ & $\begin{array}{l}23 \\
32 \\
42\end{array}$ & $\begin{array}{l}5.6 \\
7.5 \\
9.2\end{array}$ \\
\hline $\begin{array}{l}\text { Lenešice near Louny, Czech Republic } \\
\text { population with giant specimens } \\
\qquad N=91\end{array}$ & $\begin{array}{l}\min \\
\operatorname{mean} \\
\max \end{array}$ & $\begin{array}{l}3.2 \\
6.6 \\
10\end{array}$ & $\begin{array}{l}3.3 \\
6.5 \\
9.1\end{array}$ & $\begin{array}{l}1 \\
1.03 \\
1.15\end{array}$ & $\begin{array}{l}94 \\
115.5 \\
143\end{array}$ & $\begin{array}{l}155 \\
167.8 \\
176\end{array}$ & $\begin{array}{l}24 \\
49 \\
68\end{array}$ & $\begin{array}{r}3.2 \\
7.8 \\
12.4\end{array}$ \\
\hline $\begin{array}{l}\text { Dover, Kent, Great Britain } \\
\qquad N=45\end{array}$ & $\begin{array}{c}\min \\
\operatorname{mean} \\
\max \end{array}$ & $\begin{array}{l}4 \\
5.6 \\
7.4\end{array}$ & $\begin{array}{l}3.8 \\
5.4 \\
7.3\end{array}$ & $\begin{array}{l}0.95 \\
1.05 \\
1.22\end{array}$ & $\begin{array}{l}85 \\
107.5 \\
123\end{array}$ & $\begin{array}{l}160 \\
170.7 \\
178\end{array}$ & $\begin{array}{l}28 \\
51 \\
74\end{array}$ & $\begin{array}{r}6.2 \\
9.5 \\
15.2\end{array}$ \\
\hline $\begin{array}{l}\text { All measurements } \\
\qquad N=179\end{array}$ & $\begin{array}{c}\min \\
\operatorname{mean} \\
\max \end{array}$ & $\begin{array}{c}3.2 \\
5.8 \\
10\end{array}$ & $\begin{array}{l}3.3 \\
5.7 \\
9.1\end{array}$ & $\begin{array}{l}0.9 \\
1.03 \\
1.36\end{array}$ & $\begin{array}{l}85 \\
113.3 \\
143\end{array}$ & $\begin{array}{l}155 \\
169.2 \\
178\end{array}$ & $\begin{array}{l}23 \\
46.6 \\
74\end{array}$ & $\begin{array}{r}3.2 \\
8.2 \\
15.2\end{array}$ \\
\hline
\end{tabular}

pp. 1852 Terebratulina gracilis, Schl. sp. - Davidson, pp. 38-40, pl. 2, figs 16, 17, ?15 (non? 13, non 14).

1866 Terebratulina rigida, Sow. sp. 1829. - Schloenbach, pp. 283-287, pl. 38, figs 10-17.

$v 1873$ Terebratulina gracilis Schloth. sp. - Geinitz, pp. 24, 25, pl. 7, figs 18 a-e.

+ 1881 Terebratulina gracilis, Schloth., var. lata, Etheridge. - Etheridge, p. 147, pl. 3, fig. 14.

v 1889 Terebratulina gracilis, v. Schlotheim. - Frič, pp. 82, 83, text-fig. 89.

1974 Chlidonophora subgracilis (Orbigny, 1850). - Katz, p. 256, pl. 84, figs 6a-g.

1977 Terebratulina subgracilis (Orbigny). - Titova, p. 79, pl. 9, fig. 3a-g.

1991 Terebratulina lata (Etheridge, 1881). - Tarkowski, pp. 98, 99, pl. 5, figs 13a, b.

1996 Terebratulina lata (Etheridge). - Tarkowski, pl. 2, fig. 5.

v 1997 Terebratulina lata Etheridge, 1881. - Gaspard, p. 154 , pl. 1, fig. 1 .

2002 Terebratulina lata (R. Etheridge). - Owen, pp. 92, 93 , pl. 13, fig. 3.

Emended diagnosis. - Small to medium-sized, with a dropshaped or subcircular outline, ventri-biconvex to planoconvex and even concavoconvex. Costellae numerous, fine to strong, granulate or beaded. Beak short, erect to incurved, foramen small, deltidial plates disjunct, extended, adjacent a dorsal-valve margin. Hinge line relatively straight.

Description. - Exterior: Exemplars are very variable in outline, usually slightly longer than wide (Table 1,
Fig. 12C). Outline of the shell is droplike (Fig. 8A, B), slightly transversally oval (Fig. 8C), subheptagonal (Fig. 8D) or even almost square with rounded corners (Fig. 9A). The apical angle ranges from 85 to $143^{\circ}$. The shell is rectimarginate to slightly uniplicate, lateral commissure more or less straight, usually faintly incurved ventrally in its middle part. Lateral profile is ventri-biconvex to almost planoconvex (giant specimens often seem to be concavoconvex, but this is due to compression in all the observed specimens), costellate. Number of rounded costellae varies between 23-(47)-74 at the commissure. The number increases anteriorly due to intercalation and also, but rarely, true bifurcation (e.g., Fig. 7A) of about 8-10 main ribs formed in early ephebic stage. The surface of well preserved shells bears ornamentation consisting of ring-shaped thickening of costellae, parallel to growth lines. The shell is punctate.

The ventral valve is markedly more convex (often deeper in specimens from white-chalk facies), deepest in the posterior third of its length, remarkably medially flattened to faintly sulcate in the majority of specimens. Beak is erect in general but curved or slightly suberect in some specimens (generally more curved in specimens from the white chalk, the beak curvature is not directly proportional to the size of the shell), beak ridges are sharp, small submesothyrid foramen is longer than wide, deltidial plates are relatively short, disjunct, flat to slightly convex.

The dorsal valve is moderately convex in its posterior part, more or less flattened in its anterior half. Hinge margin is almost straight [155-(169)-178 ], rather wide (40-70\% of maximum shell width), in some specimens faintly projecting out of the valve outline forming tiny ears 
A
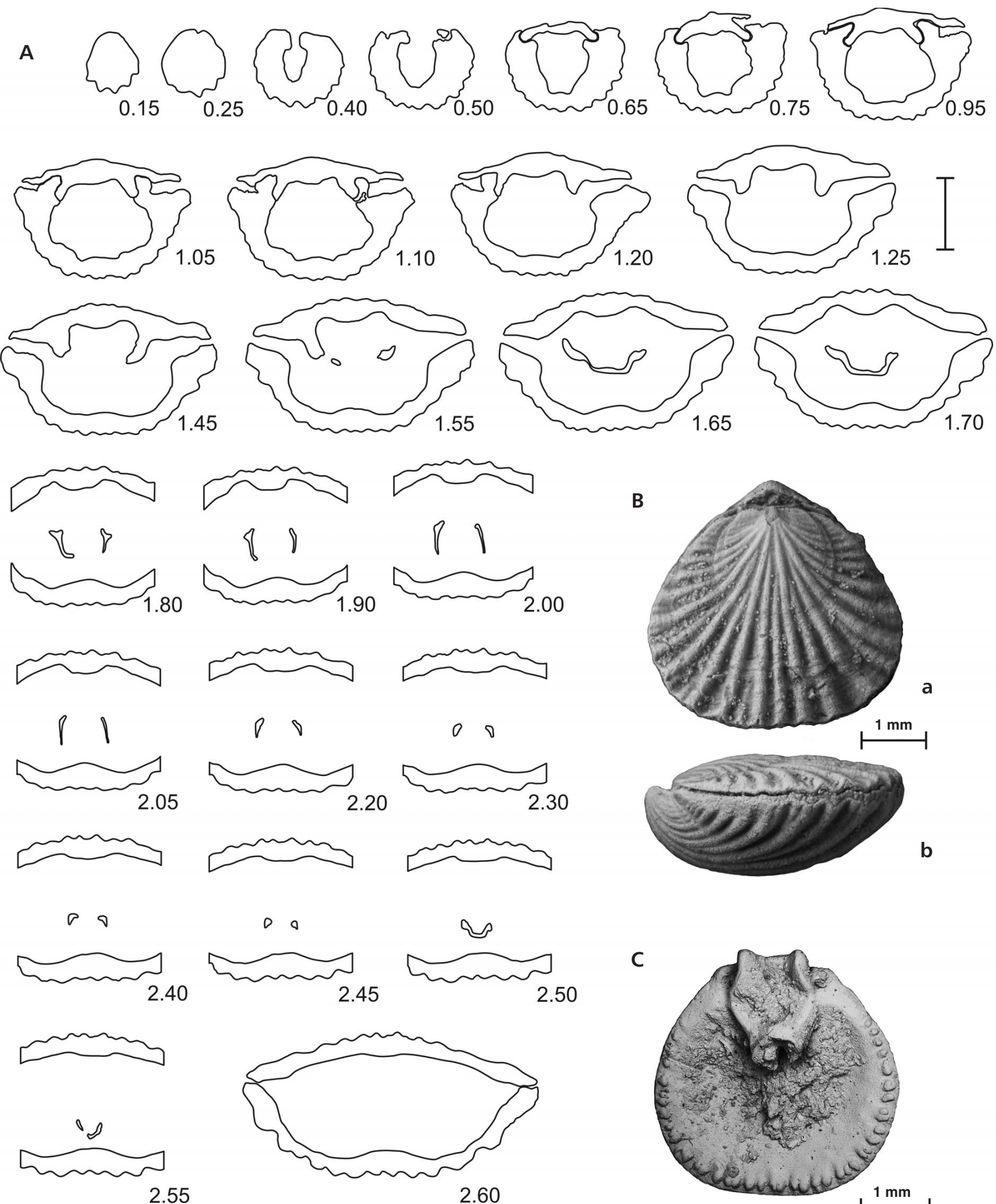

b

\subsection{5}

2.60

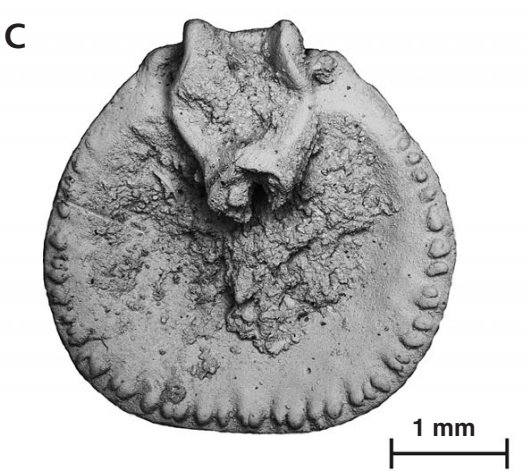

Figure 4. Gyrosoria lata (Etheridge), Úpohlavy quarry near Lovosice, NW Bohemia, Czech Republic. • A - transverse serial sections through the umbonal portion of an adult specimen (NM - d 32/2008), Teplice Formation, unit Xa. Distance from the tip of ventral umbo of each section given in mm. Drawings from peels. $\bullet \mathrm{B}$ - outer view of the specimen sectioned, covered with ammonium chloride, $\mathrm{a}-\mathrm{dorsal}$ view, $\mathrm{b}-\mathrm{lateral}$ view. $\bullet \mathrm{C}-\mathrm{dorsal}$ valve, ventral view showing dorsal internalia - prominent inner socket ridges, ascending crura and the ring of a typical cancellothyridid loop. A dissected specimen (NM - O 6821), Teplice Formation, unit Xb $\beta$, SEM. 
(Figs 8D, 9A). Different, more gentle and straight costellae can usually be observed at the postero-lateral margins (Fig. 9A).

Interior: Internal margins of the shell between the ribs of outer costellae are thickened with submarginal tubercles bearing medial grooves (Fig. 7G), which are supposed to accommodate setae. These structures are developed throughout the entire margin of the anterior half of the ventral valve and in the matching part of the dorsal one. Muscle scars are shallow and rather indistinct. A rounded and broad elevation formed from secondary shell arises from the floor of the posterior half of both valves in a medial plane of symmetry. For illustration of this text see serial sections in Figs 4A, 5A and dissected valves (Figs 4C, 6).

Ventral valve: There are 3 out of 9 sectioned specimens showing a pedicle collar. Teeth are strong, relatively long and oblique to the hinge axis, including a variable angle between $80-110^{\circ}$.

Dorsal valve: Cardinal process is very low, rather indistinct, short, sunk between strong and high elevated inner socket ridges, slightly projecting out of the posterior margin. Outer socket ridges are extremely low, almost absent. Inner socket ridges band anteriorly from the medial symmetry plane and their anterior end pass to the slightly narrower crural bases. From the very beginning convergent, relatively thick crura arise in a ventral direction becoming slightly concave dorsally in the anterior part. The crura are as long as the inner socket ridges. From their anterior ends project crural processes, fusing to form a considerably long, ventrally deflected ventral ribbon of the ring. Thin, antero-dorsally ascending branches project from its lateral margins. Their dorsal ends become folded medially and these deflected margins form a second, dorsal horizontal ribbon, sharply deflected ventrally. The dorsal extremity of the loop nearly reaches the medial convexity of the ventral-valve floor. The structure of the loop shows comparatively high variability in its angle of crural convergence as well as in orientation of the ring to the ventral-valve floor and in outline of the dorsal ribbon deflection. As the medial fold of the dorsal ribbon shows a very variable width, the ring can exhibit a subtriangular to widely subtrapezoidal outline.

Comments on measurements. - 179 specimens of G. lata from the Bohemian and English localities were measured (Table 1). The minimal, maximal and mean value of the measurements are given for three different samples as well as for the whole set of measurements. Measurements are very variable within, as well as between the investigated populations. Features such as apical angle $(\beta)$, width $(\mathrm{W})$, length (L) and thickness (T) or number of costellae are extremely variable. Moreover, the first four characters are in many clusters strongly affected by post mortal factors such as diagenetic compression (a remarkable aspect in material from marls). This makes measurement of even the thickness and in fact also the apical angle of the ventral valve rather meaningless. However the L/W ratio seems to be less affected. On the contrary, the hinge angle $(\gamma)$ proved to be a firm and useful character. This feature, as the dorsal valve is rather flat, shows a much lower influence of compression and can be easily measured in a compatible way by more than only one author. It has proved to be an invaluable differentiation character at least within the genus Gyrosoria and is one of the most significant and stable distinctive features between the two species studied in this paper (Fig. 13).

Size distribution of the species differs in the populations studied. This feature, represented by length, is shown in the histograms in Fig. 2. The common form inhabiting hemipelagic marl facies (e.g., of the Mons Basin and the BCB) is relatively small (Table 1, Fig. 2B), with rather coarser costellae. Individuals from the white chalk facies (NW Anglo-Paris Basin) are somewhat larger (the Dover cluster in Table 1 and Fig. 2C) and their costellae slightly gentler. These specimens also often show a curved beak and noticeably deeper ventral valve. Apart from these two forms, populations with prevailing gigantic specimens have also been recorded. These are known from the hemipelagic facies of the western part of the BCB (Fig. 1). The giant specimens reach up to more than $10 \mathrm{~mm}$ in length (Table 1, Fig. 2A) and bear gentle, multiple costellae. The size-distribution of their populations is noticeably discrete from that recorded in populations of the common form from biotopes influenced by marl sedimentation. However this distinction is not prominent enough to make any taxonomical conclusions. Moreover it falls within an interval of the most frequent size of white-chalk forms (Fig. 2). According to Gaspard (1997) such a dimorphism is a quite frequent phenomenon among brachiopod populations. Factors controlling distribution of this gigantic form are still unclear, but locally optimal trophic conditions come into question. This hypothesis is supported by a contemporary short-term peak of nutrient conditions within the part of the basin recorded in the Xb unit (Wiese et al. 2004), which could be locally intensified by the influence of bottom currents.

Spicular skeletons. - Connective tissues of terebratulide brachiopods are typically spiculous (Williams et al. 1997). These elements merge forming a meshwork at the mantle surface facing the mantle cavity. Especially in shortlooped representatives they also create a support for the lophophore (Lee et al. 2006). Both structures have been found within dissected specimens of G. lata. Specimens showing these features have been found at outcrops of the Úpohlavy quarry (Upper Turonian). There are five specimens showing remains of a recrystallised mantle skeleton. 

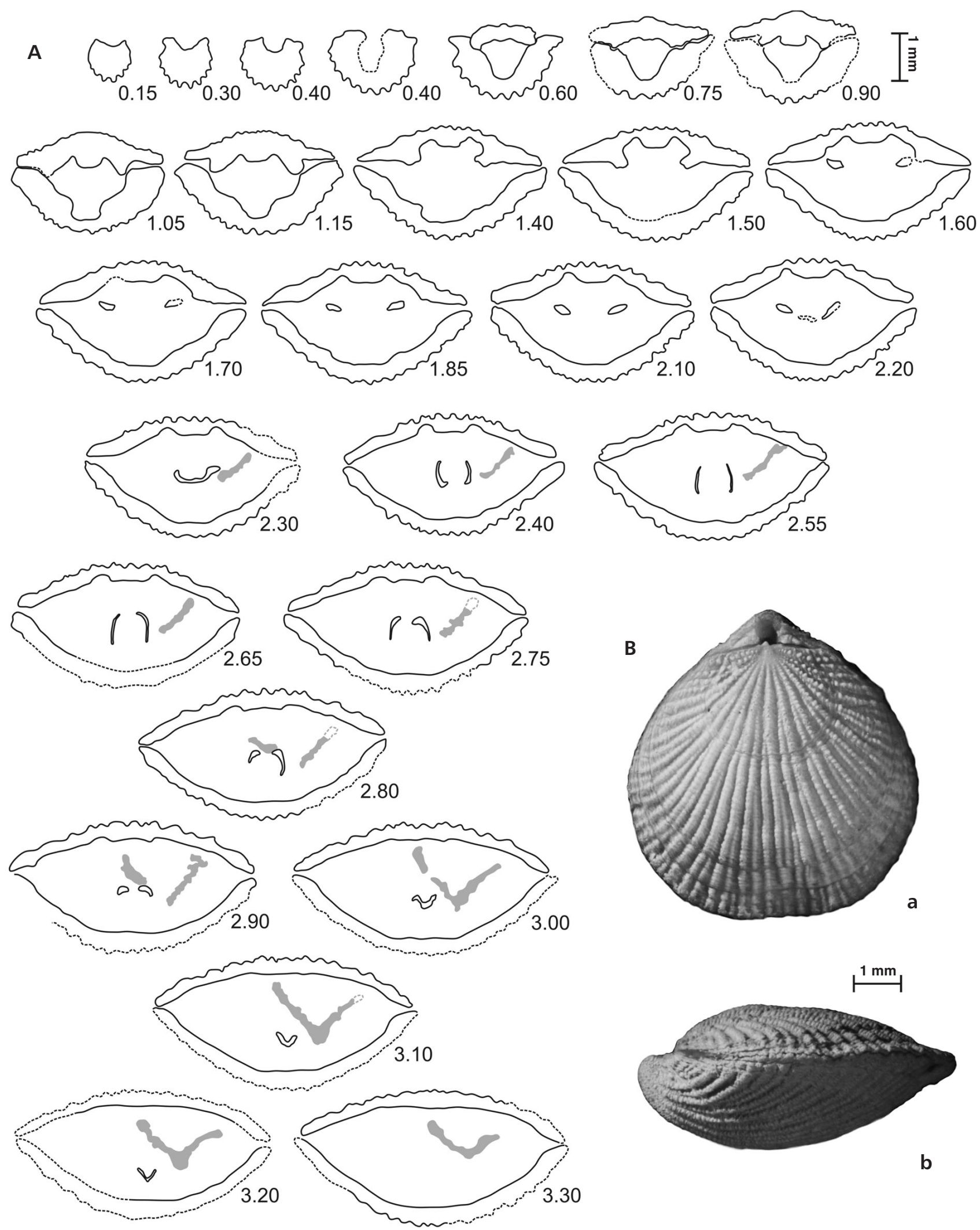

b

Figure 5. Gyrosoria lata (Etheridge), Dover (Kent), Great Britain. Middle Chalk. • A - transverse serial sections through the umbonal portion of an adult specimen (NM - d 33/2008). Distance from the tip of ventral umbo of each section given in mm. Drawings from peels, spicular framework delineated in grey. $\bullet \mathrm{B}$ - outer view of the specimen sectioned, covered with ammonium chloride, a - dorsal view, $\mathrm{b}-$ lateral view. 
It is not well preserved and rather indistinct, but in two specimens (NM O 6819, 6822) a posterior part of the structure, attached antero-laterally to the dorsal part of the loop can be clearly observed. There is a short, subtriangular opening in front of the middle part of the loop (Fig. 6Aa2). The skeleton is ventrally convex in the middle transverse cross section, medially flattened, laterally concave and sinking anteriorly to the dorsal-valve floor. Lateral wings of the structure project slightly behind the front of the brachidium. The shape described here can also be observed in the serial sections presented by Titova (1977, p. 80, fig. 5, cf. Fig. 5).

Remains of the lophophore spicular support were found in two of our specimens. One of them (NM O 6822) shows an only poorly preserved ventral, proximal part of the structure, while the second one (NM O 6820), dissected through the dorsal valve, allows us to study a major part of the dorsal segment. This part consists of zygolophe branches showing a typical lace-like edge (Fig. 6Ba), also well known from recent relatives ( $T$. retusa Linnaeus, 1758; Schumann 1973), originally accommodating bases of tentacles. Basal tube-like spiculae, which were shown by Schumann (1973) to be supportive structures of the tentacles, were not preserved. However these parts can be observed on one of two specimens of $G$. gracilis figured by Steinich (1965, pl. 12, fig.1). As this author succeeded to clean the structure almost completely from both ventral as well as dorsal sides, our remains of the G. lata structure can be easily compared with it. The preserved part of the meshwork seems to be identical. However, this result is in no way surprising as the architecture of the lophophoral skeleton is very persistent among the whole family and consequently of almost no value for detailed taxonomy. Lophophores of adult Gyrosoria individuals seem to be of relatively the same size as those of other, recent cancellothyridoids of similar size (e.g. Chlidonophora).

Shell structure. - The shell is remarkably thick, endopunctate. The primary layer of the shell is thickened at the ribs, increasing their height and partially producing the typical fine ring-like ornamentation. The secondary shell is usually relatively thick (Fig. 7).

Endopunctae penetrating the shell wall are a remarkable structural feature of Gyrosoria. Openings of these distally funnel-like perforations, going through the shell create a quincunx pattern on the outer surface (Fig. 7A, B). On the internal surfaces of this species they originated at grooves between submarginal tubercles and moved relatively in a posteromedial direction during growth of the valve (Fig. 7G). Consequently internal punctae openings compose longitudinal rows. Internal openings are faintly funnel-shaped and at the funnel bottom their diameter varies by about $4.5 \mu \mathrm{m}$ (median value, $\mathrm{N}=16$, one specimen, Autreppe, Fig. 7G). The puncta are slightly extero-anteriorly oblique to the transverse plane, so each of them can be observed only in part in serial sections (Fig. 7C-E). Moreover their external endings incline to the sides of the ribs (Fig. 7C). Density of the outer openings is reported by Steinich (1965) for G. gracilis. This character seems to be rather variable in $G$. lata both within a population and even slightly during growth of an individual. Density of the punctae varies between 260 and $780 \mathrm{pct} / \mathrm{mm}^{2}$ [measured on samples from Úpohlavy quarry and Autreppe $(\mathrm{N}=4)]$. The mean value $\left(474 \mathrm{pct} / \mathrm{mm}^{2}\right)$ is remarkably higher than the number given by Steinich (ca $250-370 \mathrm{pct} / \mathrm{mm}^{2}$ ). However Steinich published this for only one specimen, thus conclusions about a significant difference stemming from such a comparison would be ill advised (in fact for one of the measured $G$. lata specimens these values were 260-320 pct $/ \mathrm{mm}^{2}$ ). Steinich also published diameters of punctae of $G$. gracilis ( $c$ a 20-38 $\mu \mathrm{m}$ ). However distal-diameter measurements of the puncta depend on preservation of the outer shell surface (Fig. 7A, B) as the diameter increases rapidly through the primary layer. Recrystallized canopies of punctae can be observed on well preserved outer surfaces of $G$. lata. Their mean diameter varies around $24 \mu \mathrm{m}$, mean diameter of the punctae opening close to surface varies around 8-9 $\mu \mathrm{m}$.

Taxonomical remarks. - G. lata is remarkably abundant within some sedimentological units. Most of the authors in the $19^{\text {th }}$ century considered this form to fall within " $T$. gracilis" von Schlotheim and this practice was continued until recent times by many authors (Rowe 1901, Zahálka 1918, Čech 1995). The main distinctive features between these two species are convexity of the dorsal valve (almost flat to naturally concave in G. gracilis), and character of the costellae (showing usually much more prominent concentric ornamentation in G. gracilis). The typical G. gracilis of the white chalk facies is moreover very distinct due to its subcircular shape, extremely small foramen and growth of the adult specimens (up to more than $13 \mathrm{~mm}$ in length (Steinich 1965). The clearest distinctive features are the apical

Figure 6. Spicular meshwork of Gyrosoria lata (Etheridge), Úpohlavy quarry, Upper Turonian, Teplice Formation, unit Xbß (see material and methods for comments). $\bullet \mathrm{A}$ - inner view of the dorsal valve of a specimen (NM - O 6819) showing recrystalised remains of mantle spicular skeleton attached to the antero-dorsal part of the brachidial ring, a - ventral view, b - lateral view. $\bullet$ B - ventral valve of a dissected specimen (NM - O 6820 ) with remains of posterior part of the dorsal valve showing an in situ preserved spicular support of the lophophore, a - dorsal view, a2 - detail of the left branch of the plectolophe brachidium, lower arrow showing the lace-like edge, the upper arrow showing amalgamated spiculae, b-lateral, c-frontal view. SEM photography, JEOL, FSCU, Prague. 


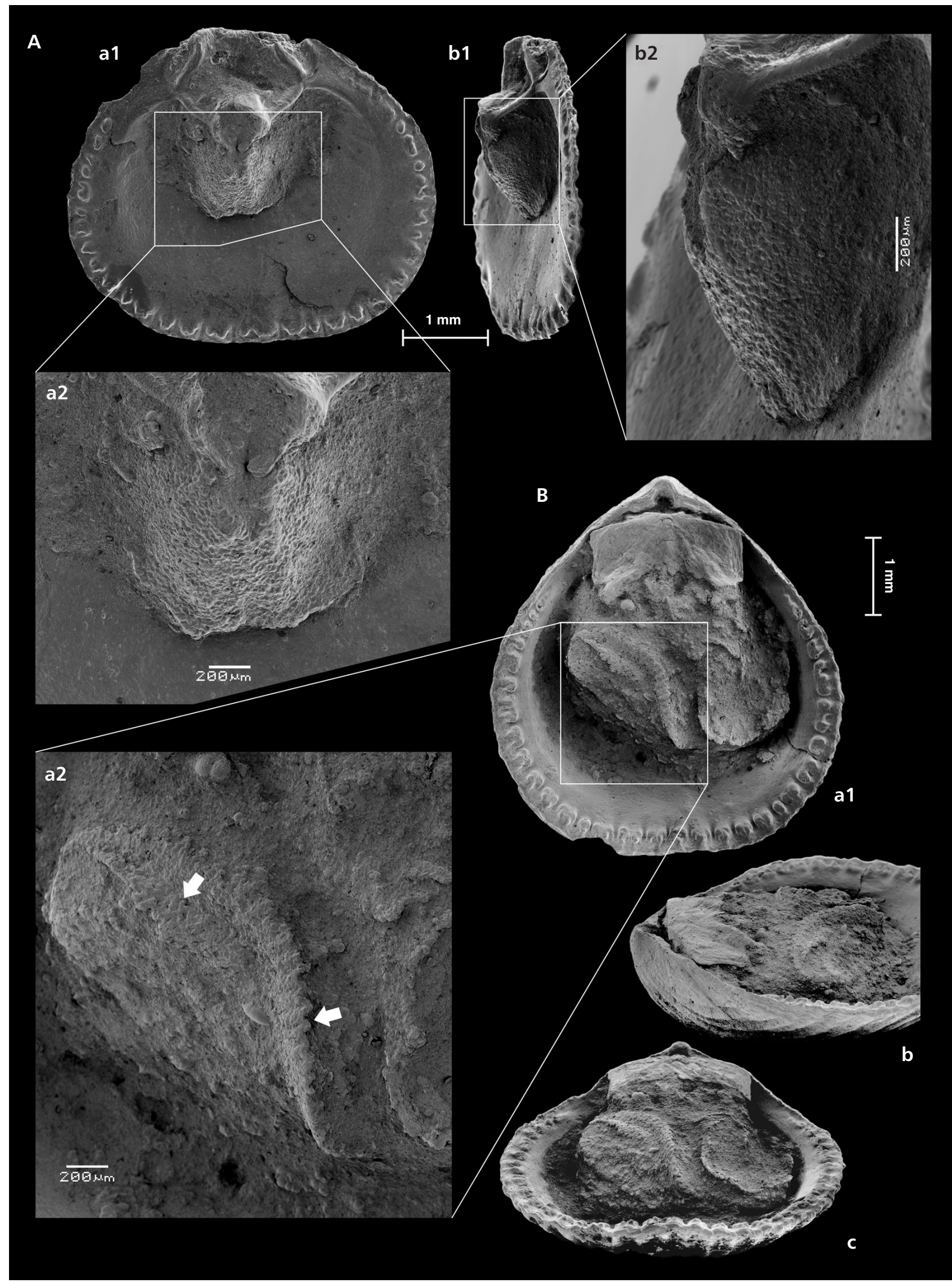



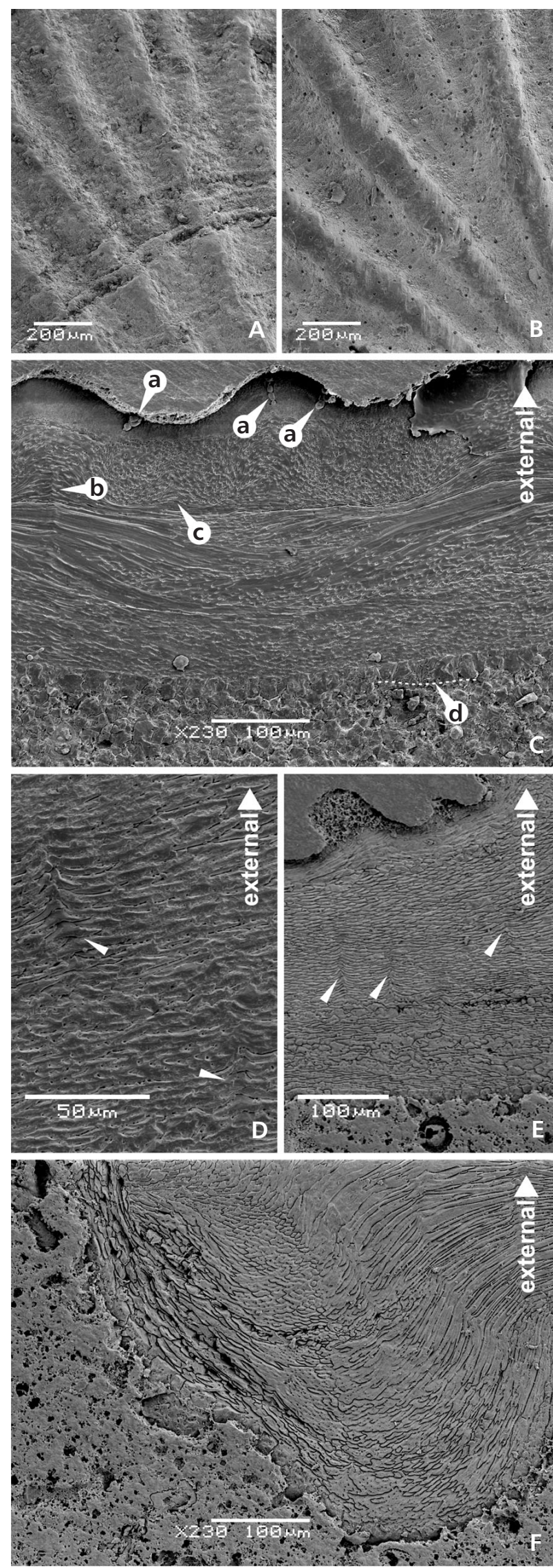

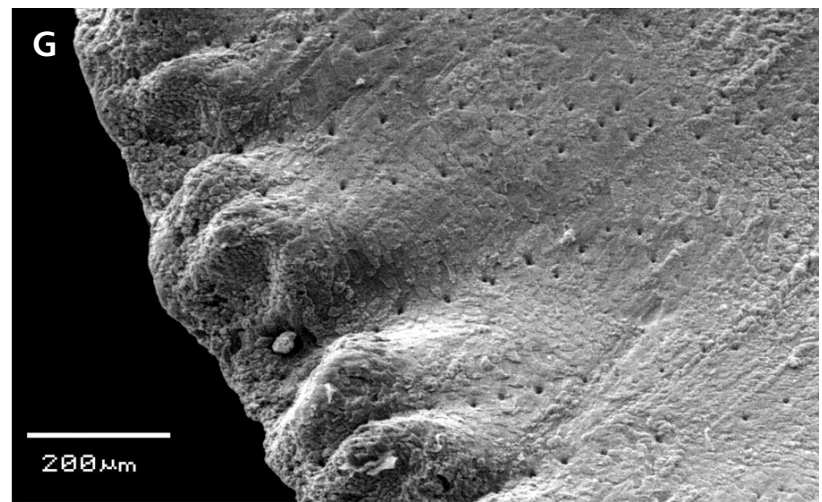

Figure 7. Detailed views of the outer surfaces and the shell structure of Gyrosoria lata (Etheridge). • A - detail of the outer shell surface of a specimen from Úpohlavy quarry, Upper Turonian, Teplice Formation, unit $\mathrm{Xb} \beta$ (see material and methods for comments) showing the quincunx pattern of the recrystalised canopies of the outer openings of puncta. See growthlines in the lower part of the figure. $\bullet \mathrm{B}$ - worn outer surface of a specimen from the same locality and formation, unit Xa, showing the pattern of the puncta openings directly below the original surface. $\bullet \mathrm{C}-$ medial transverse section $(2.55 \mathrm{~mm}$ from posterior) of the ventral valve of a specimen from Holovousy, Middle? Turonian, a - outer terminations of the puncta, $\mathrm{b}$ - a punctum sectioned within the secondary layer, $\mathrm{c}-$ initiation of an intercalated rib, $\mathrm{d}$ - internal surface/sediment boundary, the surface is partially recrystalised. Note the zig-zag change of the fibre-growth direction (in the middle of the figure), often observed around the medial symmetry plane in sections of both valves. $\bullet \mathrm{D}$ - detail of the same section showing character of the punctae. $\bullet \mathrm{E}-$ lateral part of the dorsal valve showing puncta penetrating secondary shell fibres, a specimen from the Middle Chalk of Dover (section $1.75 \mathrm{~mm}$, general sections of this specimen given in Fig. 5). $\bullet \mathrm{F}-$ a transverse section through right inner socket ridge of the same section as in D showing the anvil-shaped secondary shell fibres bent anteriorly at the ventro-medial side of the structure. SEM photos, JEOL, FSCU, Prague. $\bullet \mathrm{G}$ - inner surface of the dorsal valve of a specimen from Autreppe (IRScNB, I.G. 10511) showing character of the submarginal tubercles. Notice the internal openings of puncta and their relation to the grooves in and between the tubercles. SEM photo, Philips, IRScNB, Brussels.

Figure 8. Gyrosoria lata (Etheridge). Adult specimens from a population showing high variability in shell morphology and growth. Material collected by Nekvasilová (between 1967-1972) from outcrops in the former brickyard at Lenešice, near Louny, NW Bohemia. Whitish clayey limestones of Upper Turonian age, Teplice Formation, Xb. a - dorsal view, $\mathrm{b}$ - lateral view, $\mathrm{c}$ - ventral view, $\mathrm{d}$ - anterior view, e - posterior view, $\mathrm{f}$ - detailed lateral view of the beak, $\mathrm{g}$ - detailed dorsal view of the beak and posterior part of the shell, $\mathrm{h}$ - detail of the costellae of the dorsal valve. a-e - whitened with ammonium chloride, $\mathrm{f}-\mathrm{h}$ - SEM photos, Philips, IRScNB. • A - small, ventribiconvex specimen (NM - O 6814) with tiny pedicle opening, considerably coarse-costellate, with prominent growthlines which is, in localities within $\mathrm{BCB}$, the most common shape. - B-D - very large specimens with rather fine costellae. Populations of individuals showing such morphological features occur rather rarely, also in a few other localities of western part of BCB (see Material and methods, Fig. 1), B - specimen with drop-like outline and narrow hinge (NM-O 6815), C - very wide, oval specimen (NM - O 6816), D - subheptagonal specimen (NM - O 6817). 


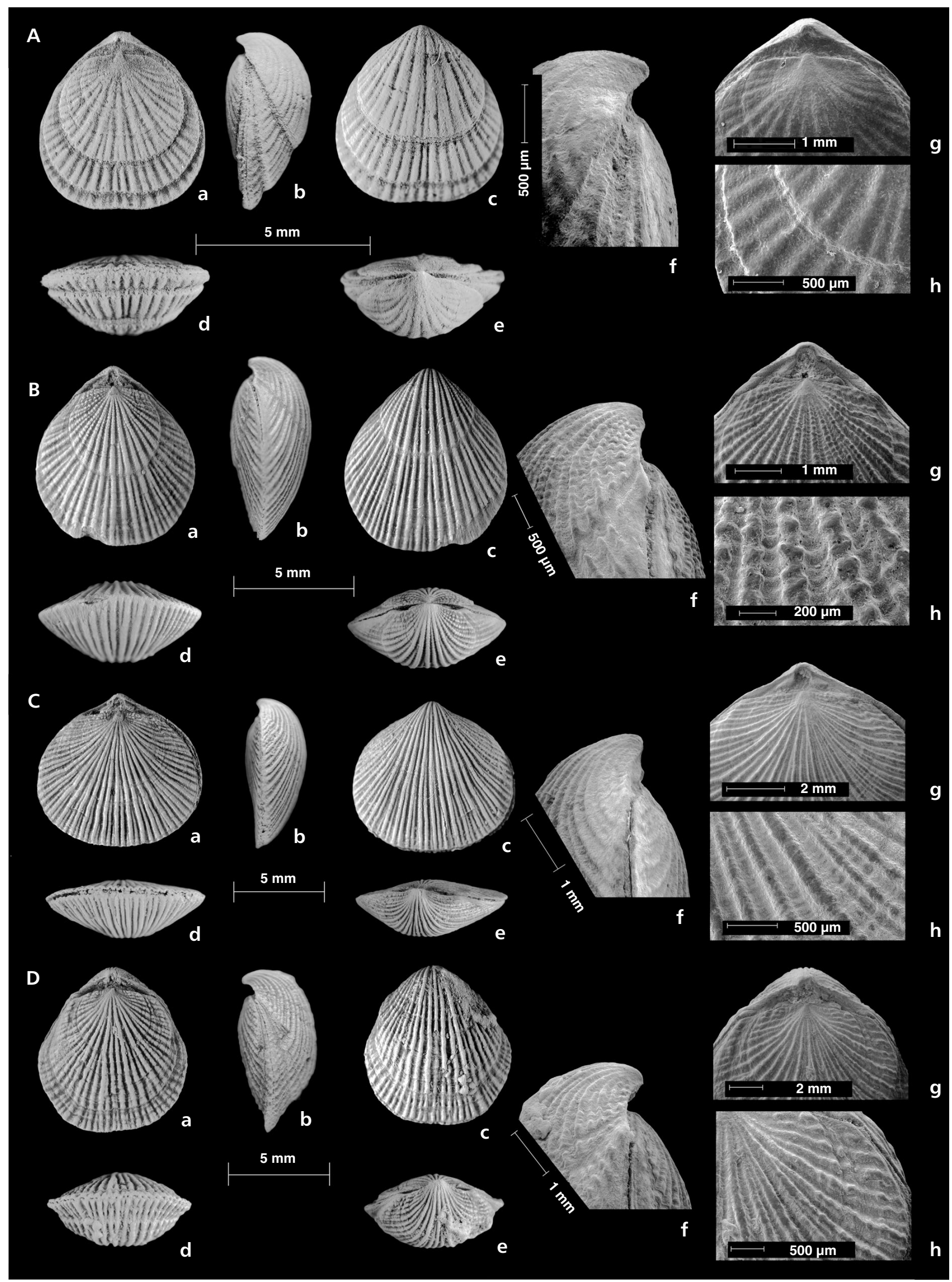


angles of the ventral $(\beta)$ and especially the dorsal valve $(\gamma)$. This is consistently far more obtuse in G. lata (for comparison see Tables 1, 2, Figs 12A, B, 13 and statistics of Steinich 1965). Moreover these species are distinct in their stratigraphical range: Middle to Upper Turonian, Coniacian (?) for G. lata, Upper Campanian and Maastrichtian for G. gracilis. The almost identical internal characters of both the species prove their allocation to one genus.

The most detailed, major study on G. lata was produced by Schloenbach $(1866,1868)$. He assigned this form to $T$. rigida Sowerby in both the publications and separated it distinctly from $G$. gracilis of the white chalk facies (amongst the distinctions is included the straighter hinge margin of the dorsal valve). However, the holotype of Sowerby's species stored in NHM (B-61626) is not of the same kind. The main proof for this statement is the $124^{\circ}(!)$ apical angle of the dorsal valve (see Table 1 for comparison). This suggestion is also supported by the shape of the ventral umbo and sparser ribs of the Sowerby original. Moreover dimensions of this specimen $(\mathrm{L}=8.6 \mathrm{~mm}$, $\mathrm{W}=7.8 \mathrm{~mm}$ ) show a high deviation from the mean of all the measured lata-populations. Schloenbach had probably never seen the original material and the illustration in Sowerby \& Sowerby (1829) is rather vague and differs in dimensions from the original.

The specimens described by Roemer (1841) under the name $T$. ornata probably also belong to G. lata. However, his description as well as the figure is so poor that we can only suppose that he had the same species in mind due to the localities (Weinböhla and Strehlen) quoted by him among others. This is insufficient data to be certain what he actually described and the name should be considered a nomen nudum.

Katz (1974) used the name "Chlidonophora subgracilis (Orbigny, 1850)" (with erroneous year of publication) for cancellothyrid brachiopods from the lower Upper Turonian of Dombas. He included a brief description regarding the straight posterior margin of the dorsal valve and provided figures showing the general shape of the brachidium. Although the figures are very poor it is almost certain that he was describing G. lata. Titova (1977) used the same species name for unquestionable specimens of $G$. lata found within the Turonian/Coniacian of Turkmenistan but without any reference to Katz's publication. She assigned it to the original genus Terebratulina. The name subgracilis was employed for first time, more than 120 years after d'Orbigny's creation, by these authors. Consequently it had already been at least a nomen oblitum in terms of the ICZN (\$ 23.2., International Commission on Zoological Nomenclature 1999). Furthermore d'Orbigny (1852) employed this name in an index to his "Prodrome de Paleontologie" only as a new name for the specimen (MNHN A 26089) described and figured in "Terrains Cretacés" $(1847,1849)$ as "T. gracilis". Due to the fact this had been done with no further explanation, his decision should not be considered as valid and the name should be refused as nomen nudum.

The name "lata" had been erected by Etheridge (1881). The author used this name as a variety-rank name within the "T. gracilis" species and it became used later as a species name (e.g. in Mortimore 1986, with no explicit nomenclatorial act known to the authors). As this is a species-group name according to ICZN ( $\$$ 45.1.) and it had just been elevated to the species rank, Etheridge's authorship stays unaffected (ICZN § 50.3.1.). The original (BGS - GSM 38693) from Babraham Road, Middle Chalk, had been poorly figured, but a description given by the author is clear. Etheridge (1881) did not present any description or illustrations of the internal characters, which are given here for the first time for material from the Anglo-Paris Basin and adjacent areas (Figs 4, 5).

Stratigraphical range. - G. lata is well known as a macroscopic marker for the traditional "Terebratulina lata Zone" of the Anglo-Paris Basin [zone à Terebratulina gracilis, Barrois (1876)]. The sedimentological record falling within this zone in the northern part of the basin is Middle to lowermost Upper Turonian (Middle - Upper Chalk) in age and consists of chalk/marl sediments. The range of the zone (between I. labiatus and H. planus Zones) falls within the C. woollgari ammonite Zone (Gaspard 1997).

In the Bohemian Cretaceous Basin occurrences of $G$. lata fall within a stratigraphically slightly higher position

Figure 9. Gyrosoria lata (Etheridge) and Gyrosoria gracilis (von Schlotheim). a - dorsal view, b - lateral view, c - ventral view, d - anterior view, $\mathrm{e}$ - posterior view, $\mathrm{f}$ - detailed lateral view of the beak, $\mathrm{g}$ - detailed dorsal view of the beak and posterior part of the shell, $\mathrm{h}$ - detailed view of the costellae of the dorsal valve. a-e - whitened with ammonium chloride, $\mathrm{f}-\mathrm{h}-\mathrm{SEM}$ photos, Philips, IRScNB. • A - G. lata, Lenešice, Upper Turonian, the same population as figured in Fig. 7, subtrapezoid, large specimen (NM - O 6818) with very wide hinge and slightly suberect beak. Note the remarkable differentiation of costellae in the posterolateral parts of the dorsal valve. $\bullet$ B, C - G. gracilis. Specimens adapted to a relatively high-energy environment. Material collected from a disused quarry at Altembroeck, east of 's Gravenvoeren, Province of Limburg, Belgium. Light grey glauconitic marlstone of late Early Maastrichtian age, Gulpen Formation, base of the Vijlen Member, (?) upper Belemnella sumensis Zone. B - a large adult specimen (IRScNB MI-11049), C - a smaller adult specimen (IRScNB MI- 11048). • D, E - G. gracilis specimens adapted to a low-energy environment. Material collected from the disused CBR quarry, $1.25 \mathrm{~m}$ above the Froidmont Horizon, in Hallembaye, Province of Liège, Belgium. White chalk of early Late Maastrichtian age, Vijlen member, Gulpen Formation, Belemnitella Junior Zone. D - an adult specimen (NHMM JJ 4924-1) with typical concavo-convex shell outline and strongly curved beak, E - SEM photos of another adult specimen (NHMM JJ 4924-2) illustrating detailed structures for the beak and the costellae. 

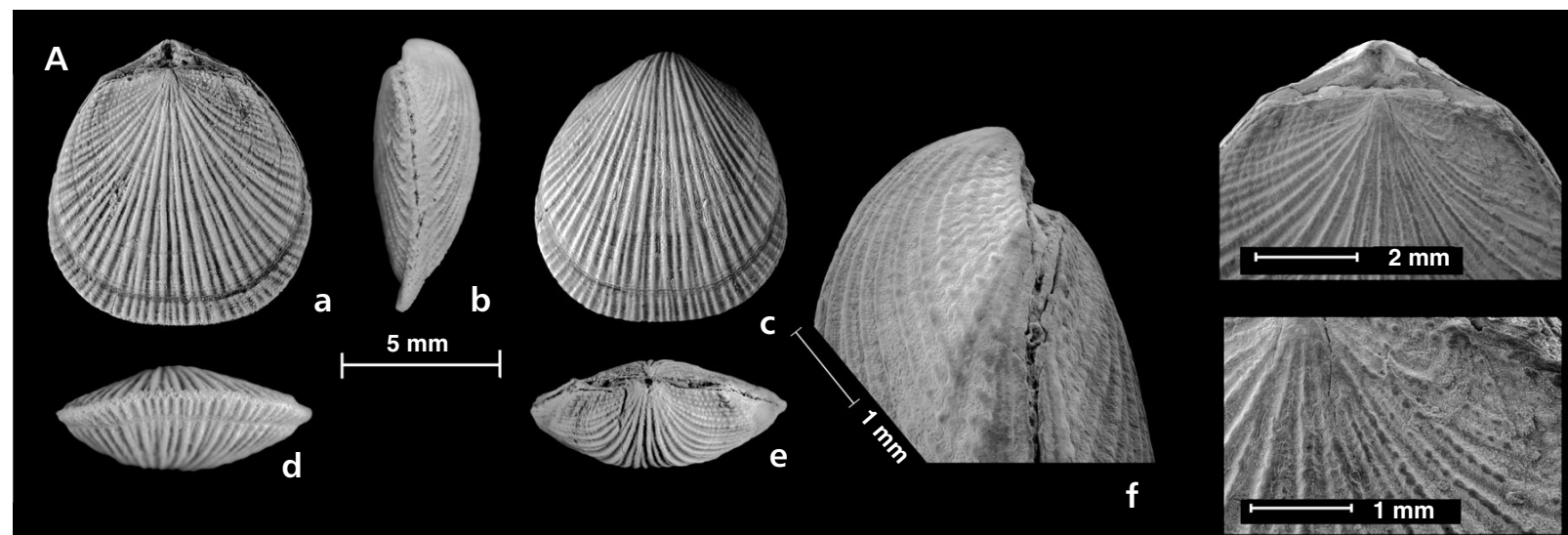

h
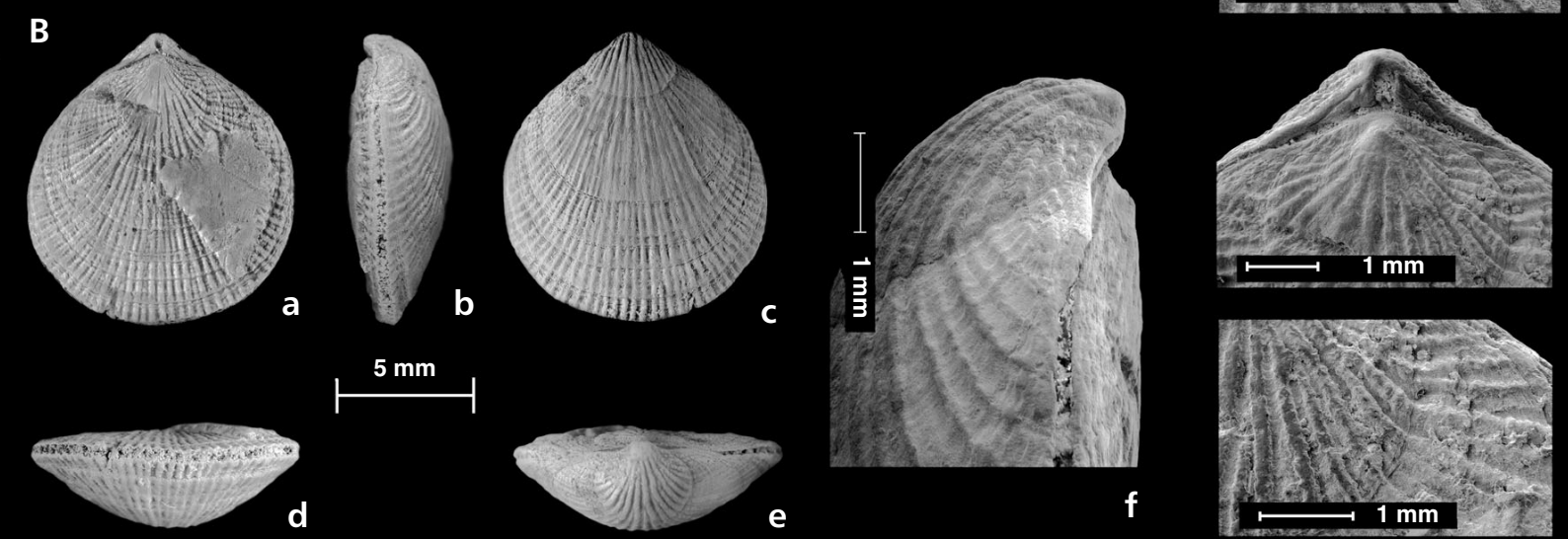

g
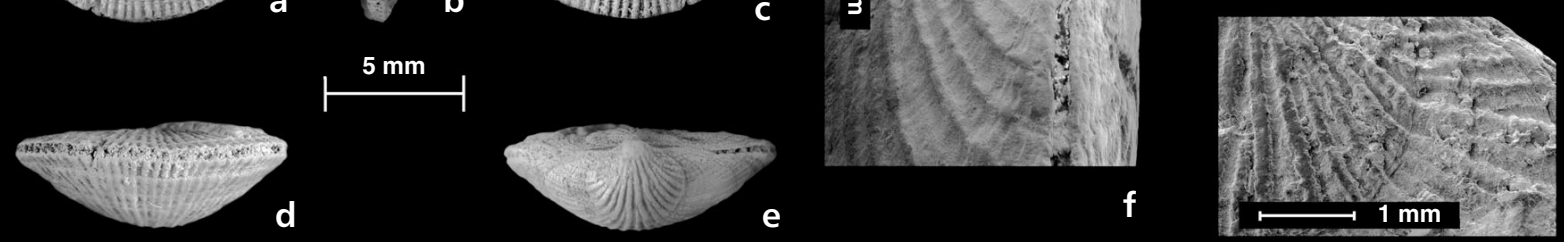

h
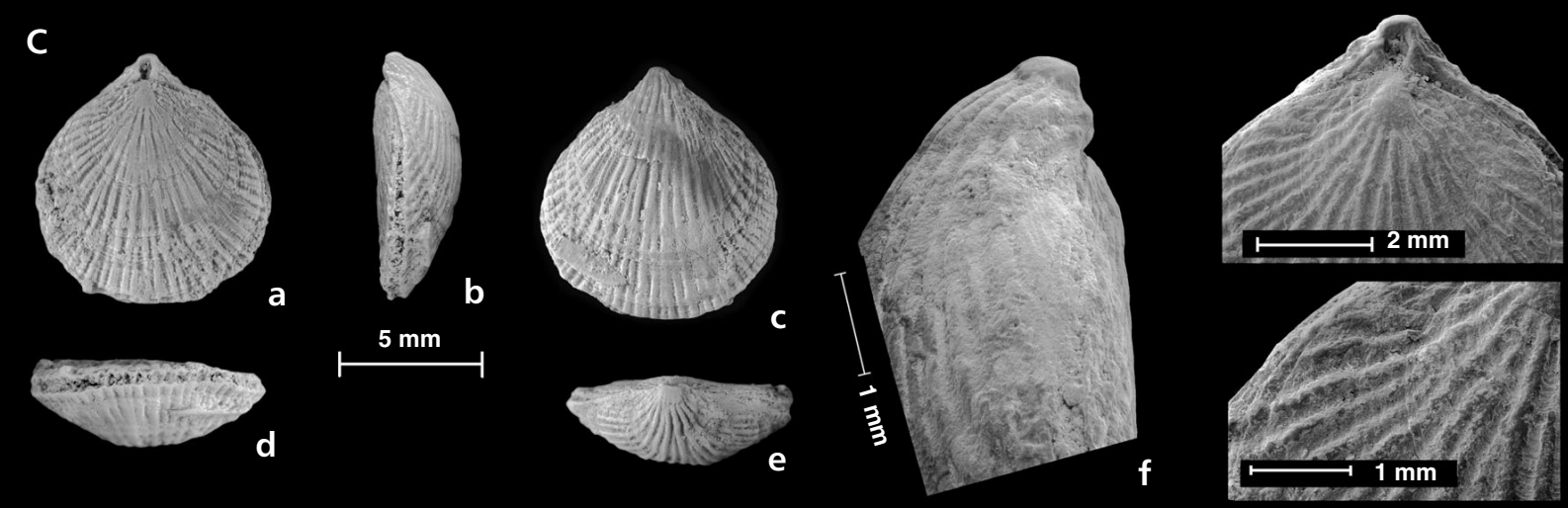

g
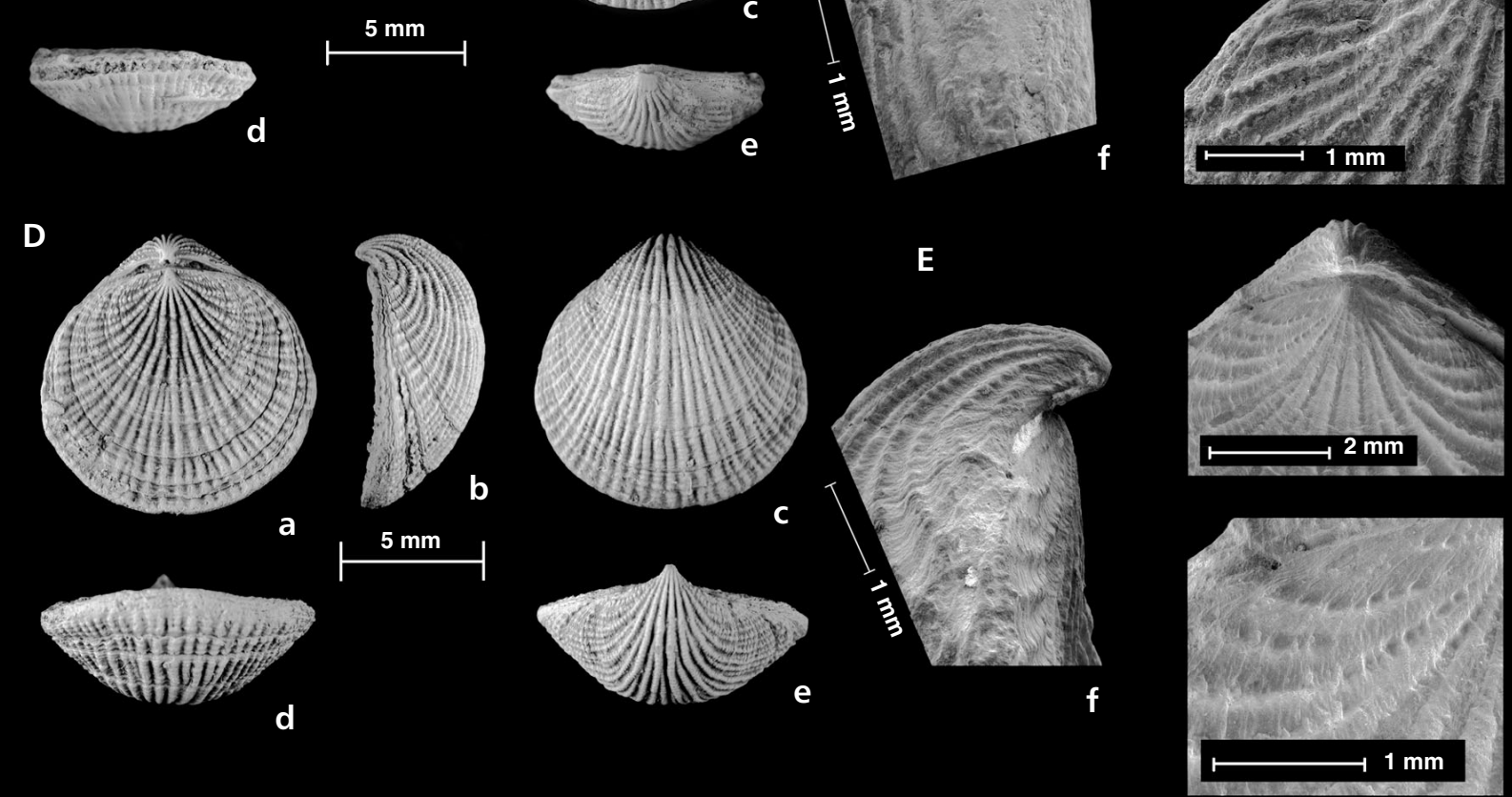
and the species is locally abundant in the early Late Turonian sediments (S. neptuni ammonite Zone, I. inequivalvis/lamarcki stuemecki/cuvieri/perplexus and I. labiatoidiformis/striatoconcentricus inoceramid assemblage zones; Wiese et al. 2004) whereas the Middle Turonian occurrences are more rare and often dubious in BCB (Material and Methods chapter).

Tarkowski (1991) reported two high-abundance bands of $G$. lata within the Turonian of the Opole basin. He placed the lower one in the Middle Turonian whereas the upper one, situated about two-three meters higher, in the Upper Turonian. The situation is remarkably similar to that recorded in the Úpohlavy section. The lower "T. lata Horizon" is situated immediately under his "I. cuvieri Zone" i.e. under the "M. leskei Horizon" of its base. Above this horizon he reports the upper "T. lata Horizon". The same development can be observed in the lower part of the Úpohlavy section (Wiese et al. 2004).

The stratigraphical range given by Titova (1977) for this species in Turkmenistan is even Turonian - Coniacian. It introduces a presumption of migration of the species from West to East of the Boreal Realm. However detailed stratigraphical revision of its occurrences in Tuarkyr, as well as data from the supposed transition areas are needed to prove this migration-hypothesis.

G. lata should remain a useful biostratigraphical marker for the purposes of regional stratigraphy. However due to the fact that it is a rather long-ranging species it cannot be recommended for any more global correlation.

Geographical distribution. - Southern England, France (Normandy), southern Belgium, Germany (Saxony), Czech Republic (Bohemia), southwestern Poland (Opole), Ukraine (Donbas), Turkmenistan (Tuarkyr area).

\section{Gyrosoria gracilis (von Schlotheim, 1813)}

Table 2, Figures 9B-E, 10-13

+1813 Terebratulites gracilis von Schlotheim, p. 113, pl. 3, figs $3 a-b$.

1965 Terebratulina gracilis (Schlottheim, 1813). - Steinich, pp. 81-93, text-figs 95-114, pl. 11, figs 1a-d; pl. 12, figs $1,2 \mathrm{a}, \mathrm{b}$; pl. 13, figs $1-3$. See for further synonymy.

1972 Terebratulina gracilis (Schlottheim). - Surlyk, pp. 24, 40, 43, 44, figs 5, 9, 11e, 13, 15b, 18, 19, 20 , 21, pl. 5, fig. c.

1973 Gyrosoria gracilis (Schlotheim). - Cooper, p. 386, pl. 45, figs 14-21.

1977 Gyrosoria gracilis (Schlotheim). - Titova, p. 77, fig. 4; p. 78, pl. 9, fig. 2, non fig. 3 (= G. lata).

1980 Terebratulina gracilis (Schlottheim). - Surlyk in Birkelund \& Bromley, fig. 26.
1980 Terebratulina gracilis. - Felder et al. in Birkelund \& Bromley, p. 127.

1982 Terebratulina gracilis Schlottheim, 1813 (sic). - Nechrikova, pp. 42, 43, pl. 4, figs 10-18.

1982 Terebratulina gracilis. - Surlyk, pp. 261, 263-265, fig. 1.

1984 Terebratulina gracilis. - Surlyk, p. 219, fig. 2.

1984 Terebratulina gracilis (Schlottheim). - Surlyk \& Johansen, fig. 1.

1987 Terebratulina gracilis (Schlottheim, 1813). - Johansen, p. 16, pl. 7, figs 7-9.

1988 Terebratulina gracilis (Schlotheim, 1813). - Johansen, fig. 2, p. 49 , pl. 1, fig. 5 .

1989a Terebratulina gracilis (Schlotheim, 1813). - Johansen, fig. 2, p. 246.

1989b Terebratulina gracilis (Schlotheim, 1813). - Johansen, p. 170, pl. 2, fig. 2, 24.

1982 Terebratulina gracilis. - Surlyk, pp. 261, 263-265, fig. 1.

1984 Terebratulina gracilis. - Surlyk, p. 219, fig. 2.

1990 Terebratulina gracilis (Schlotheim, 1813). - Johansen \& Surlyk, fig. 2, p. 844, pl. 4, figs 1-7.

1992 Gyrosoria gracilis (Schlotheim, 1813). - Titova, pp. 159, 160, pl. 77, figs 3,4 .

1993 Terebratulina gracilis (von Schlotheim, 1813). - Simon, p. 75.

1996 Terebratulina gracilis (von Schlotheim, 1813). Keutgen, fig. 25, pp. 135-137, 190.

Emended diagnosis. - Representatives from high-energy environments with a drop-shaped shell in outline, slightly ventribiconvex to planoconvex in lateral profile. Anterior commissure generally rectimarginate. Beak short, suberect to erect. Beak ridges poorly defined. Foramen incomplete, submesothyrid to permesothyrid, small to medium sized. Deltidial plates disjunct. Hinge angle between 116-130 . Free-lying representatives from low-energy environments with a typical circular shell in outline and a planoconvex to concavoconvex hemispherical lateral profile. Anterior commissure rectimarginate to very slightly parasulcate. Beak strongly curved with beak ridges nearly absent. Foramen reduced and sometimes pinhole. Deltidial plates not visible. Hinge angle between $150-160^{\circ}$. The shell of both representatives ornamented with numerous knobbed costae, laterally curved backwards, increasing by division and intercalation. Inner socket ridges thickened. Flat and elliptical cardinal process developed in adults. Brachidium with convergent crura and tube-like ring with descending branches connected by a thin dorsal bridge.

Description and variation in the species. - The material collected from white chalk facies: The von Schlotheim original material and most of the specimens illustrated during the $19^{\text {th }}$ century had been collected from white 
A
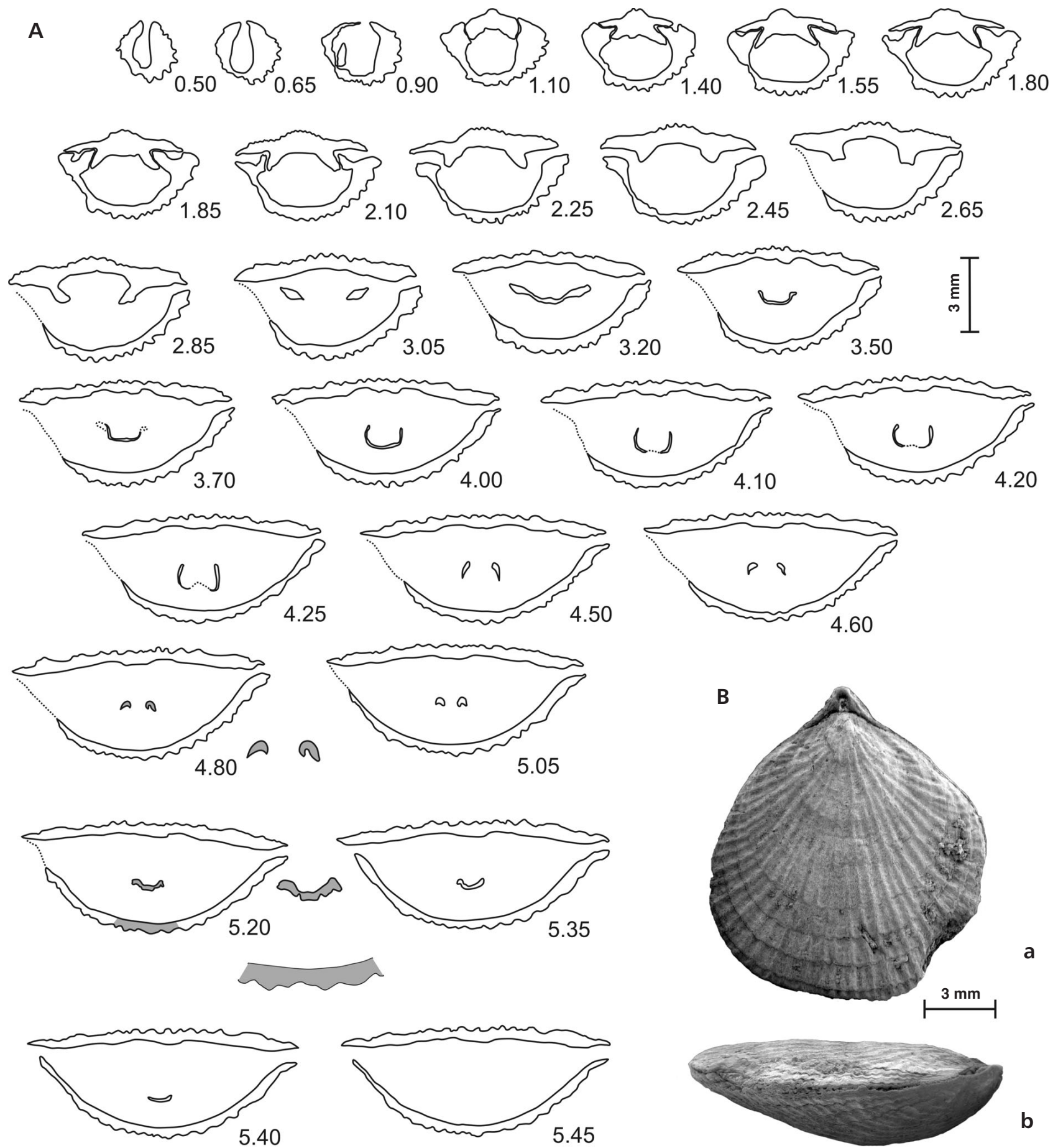

b

Figure 10. Gyrosoria gracilis (von Schlotheim), specimen IRScNB - MI-11060 (ex Bosquet colln.), from Altembroeck, 's Gravenvoeren, Province of Limburg, Belgium. (?)Late Maastrichtian, Gulpen Formation, Vijlen Member. A - transverse serial sections through the umbonal portion of an adult specimen. Distance from the tip of ventral umbo of each section given in $\mathrm{mm}$. Drawings from peels, magnified details marked with grey. $\bullet \mathrm{B}-$ outer shape of the specimen sectioned, a - dorsal view, b - lateral view. SEM photos, Philips, IRScNB.

chalk outcrops. Specimens figured in von Buch (1835), Davidson (1852), Quenstedt (1871) and in Posselt (1894) are some examples. All those historical references referred to subcircular, hemispherical ventribiconvex shells, with a strongly curved beak. Their planoconvex or even concavo- convex lateral profile had been emphasised by nearly all the authors. The submesothyrid to permesothyrid foramen is very small and limited by the deltidial plates. The shell ornamentation consists of numerous strong, finely knobbed, costellae which are relatively bent on the lateral parts 
of the valves. The brachidium with its thin convergent crura and its tube-like brachial ring had been already drawn by Quenstedt (1871, pl. 44, fig. 37).

A very exhaustive study dealing with $G$. gracilis collected from Rügen (Germany) was published by Steinich (1965). This material had also been extracted from Early Maastrichtian white chalk. This study is extremely detailed regarding this species and should be used as a valuable reference. The variation in all the morphological characters throughout growth are presented on detailed scatter diagrams (Steinich 1965). The structure and the ontogenetic growth process of the brachidium are described meticulously (Steinich 1965).

Moreover, transverse serial sections, although not fully completed (Steinich 1965, fig. 106), allow a comparison between the loop structure of $G$. gracilis collected in non white chalk facies in Belgium and the loop structure of $G$. lata with the G. gracilis white chalk material from Rügen. The similarities between all these serial sections confirm the allocation of these species to the genus Gyrosoria as already explained above. For these reasons, morphological descriptions will not be repeated here.

Surlyk (1972) published an elaborate study dealing with morphological adaptations and population structure of the Danish chalk brachiopods. Four ecological groups were determined and G. gracilis was considered as a representative of the ecological group of medium to large sized secondarily free living forms. Surlyk (1972) insisted on the fact that a hemispherical outline is uncommon amongst Mesozoic brachiopods and that it had been developed in several species which are not taxonomically related. In fact, this outline is an excellent adaptation for free-lying (Richardson 1997) especially on the sea bottom. G. gracilis shared this adaptation with other brachiopod species such as Magas chitoniformis (von Schlotheim, 1813), Thecidea papillata, Gemmarcula humboldtii, Trigonosemus pulchellus and Meonia pulchellus. These brachiopods all have a strong hemispherical ventribiconvex outline and a curved beak with a pinhole foramen. It seems that this adaptation developed when the sediment was muddy and consisted mainly of coccoliths and small foraminifera (Surlyk 1972).
The brachiopod study from the Maastrichtian-Danian sequence at Nye Kløv, Denmark (Johansen 1987) proposed a description of G. gracilis and gave illustrations of early juvenile growth stages and of a subcircular concavoconvex adult shell (pl. 7, figs 7-9). Very similar materials were illustrated by Titova (1959, pl. 4, fig. 4a-c; 1977 , pl. 9, fig. 2a-c; 1992, pl. 77, fig. 4) for specimens collected from the Maastrichtian of the Crimea, and Turkmenistan. Belgian specimens of $G$. gracilis collected at Hallembaye (Province of Liège white chalk facies, earliest Late Maastrichtian, B. junior Zone) are identical to the German, Danish and Caucasian representatives (Fig. 9D, E).

In all these works cited above, $G$. gracilis appears, at first glance, to be a very stable species, not affected by any morphological character variation. However permanent variation in all the character measurements can be illustrated from analysis of the scatter diagrams published by Steinich (1965). If the ratio length/width of the shell has a mean value of 1.05 for well developed shells, one can observe some specimens with a ratio of 0.95 indicating transversely oval shells. Several shells, on the contrary are characterized by a ratio of approximately 1.15 suggesting an elongate oval outline. Although the hinge line angle is rather stable, with a mean value of $150^{\circ}$ (Steinich 1965), it is possible to find specimens with a hinge angle of $130^{\circ}$ to $165^{\circ}$. The most variable character remains the number of costellae (Steinich 1965) which can be twice as important for a determined width of the shell.

The material collected from Altembroeck: The material collected by fieldwork in Altembroeck yielded a large quantity of brachiopods. The brachiopod fauna is relatively diversified and comprises species with a strong pedicle such as Neoliothyrina obesa and well-preserved, free-lying Carneithyris subcardinalis. Several terebratulinid brachiopod specimens were also discovered which resemble G. gracilis. However, after long and careful observation of these shells, their taxonomic position remains doubtful. The complete description of this material is given here (Fig. 9B, C).

Figure 11. Gyrosoria gracilis (von Schlotheim). Specimens adapted to a relatively high-energy environment. Material from the BOSQUET collection, collected during the $19^{\text {th }}$ century, from temporary outcrops situated along the Gulp River between Slenaken, Pesaken and Gulpen, or in Vaals (Schneeberg), southern Limburg, The Netherlands (lacking precise data). Glauconitic chalk of Early Maastrichtian age, Gulpen Formation, base of the Vijlen Member, (?) Belemnella obtusa/ B. sumensis Zones. All material housed in the IRScNB. a - dorsal view, b-lateral view, c-ventral view, d-anterior view, e - posterior view. $\bullet$ A - specimen (IRScNB MI-11056) with a subcircular outline. The beak is relatively medium sized and erect. As seen in posterior view, the tip of the beak does not go beyond the surface of the dorsal valve. The dorsal valve is flatly convex. Collected from Vaals (Schneeberg). $\bullet$ B - specimen (IRScNB MI-11057) with a drop-shaped outline. The beak is longer and curved. As seen in posterior view the tip of the beak goes beyond the surface of the dorsal valve. This character is closer to the beak structure observed in specimens collected from the white chalk. The dorsal valve is slightly convex. Collected from Slenaken. $\bullet$ C - specimen (IRScNB MI-11058) with a drop-shaped outline. The beak, relatively short but coarse, does not go beyond the surface of the dorsal valve. The posterior part of the dorsal valve is convex but its anterior part becomes concave. The strong convexity of the ventral valve is noteworthy. This specimen resembles those collected from the white chalk facies. Collected from Slenaken/Pesaken or Gulpen. $•$ D - a much larger adult specimen (IRScNB MI-11059) with a perfect oval outline. In lateral profile the shell is strictly plano-convex. Numerous narrower, curved costellae are present. The beak is short with its tip not developed beyond the dorsal valve surface. Collected from Slenaken/Pesaken or Gulpen. 

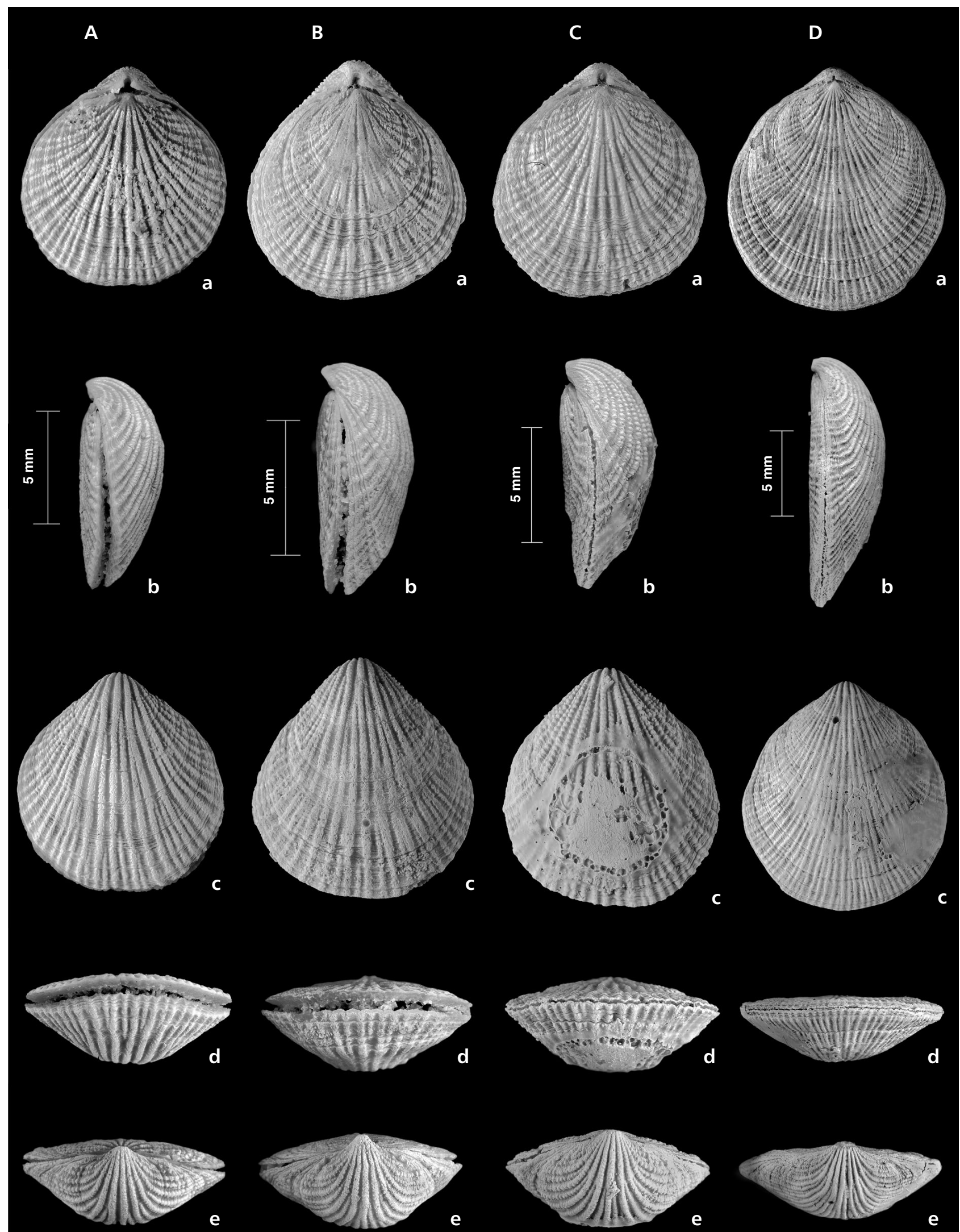
A

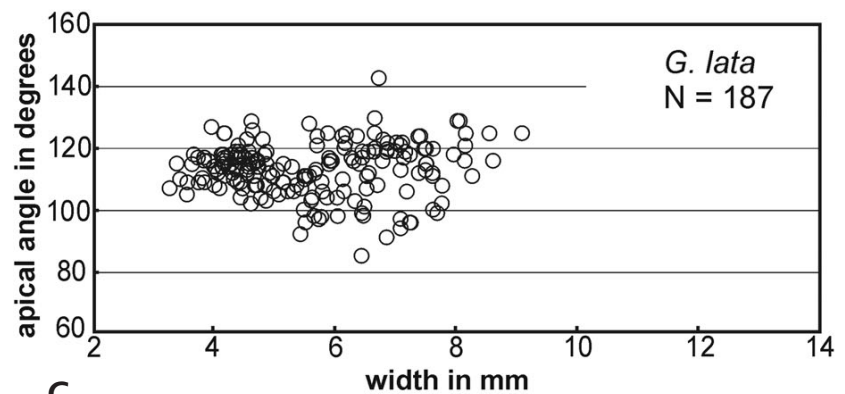

C

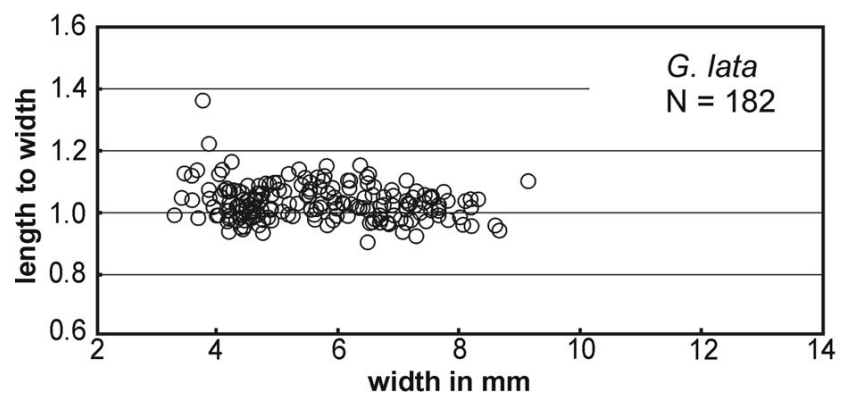

B

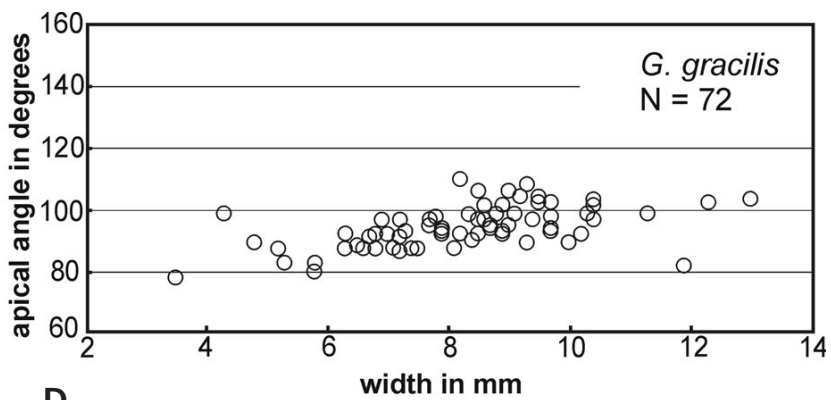

D

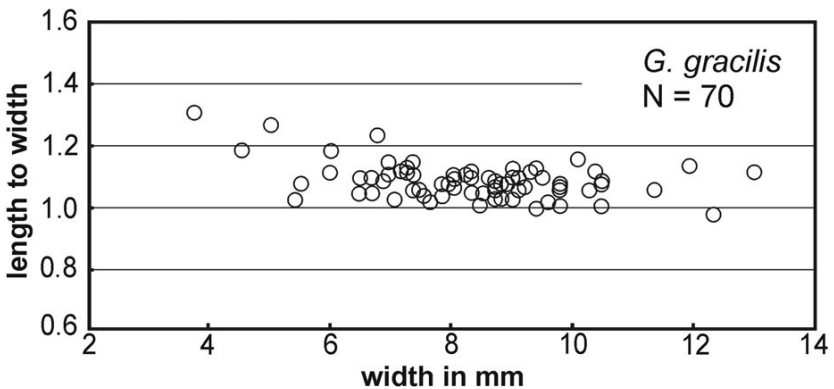

Figure 12. Plots of Gyrosoria lata and G. gracilis clusters. A, B - apical angle to width diagrams. Note that the apical angle is not width-dependent. A - a plot of 187 specimens of G. lata from Úpohlavy, Lenešice and Dover. B - a plot of 72 specimens from Altembroek, Slenaken, Pesaken, Gulpen, Vaals and unknown localities within the Limburg area. $\bullet \mathrm{C}, \mathrm{D}-$ plots showing L/W to W relation. These characters are independent. C - a plot of 182 specimens of G. lata from Úpohlavy, Lenešice and Dover. D - a plot of 70 specimens of G. gracilis from Altembroek, Slenaken, Pesaken, Gulpen, Vaals and unknown localities within the Limburg area.

The shell is medium sized (Table 2) elongate-oval in early juveniles, typically drop-shaped in small representatives and more subcircular in adults. The drop-shaped outline is sometimes visible in adult shells. In lateral profile, the juvenile and small shells are ventribiconvex as is sometimes the case in larger adult shells. But some larger shells are planoconvex. No specimens have been collected with a concavoconvex shell. The costellae are clearly developed, semisubcylindrical structures slightly bent to the lateral margin in large adult specimens. In smaller specimens the costellae are straighter. The number of costellae is variable. It reaches 75 for shells with a width of $14.6 \mathrm{~mm}$. The ratio of number of costellae/width varies from 4.9 to 6.6. The costellae appear to be rather smooth but a closer examination indicates that the shell surface has been strongly abraded. Originally, the costellae could have been more granulose or even beaded. The maximum width is at the mid-length. The auricles of the dorsal valves are not significantly developed. Several growth lines are visible. The anterior commissure is rectimarginate and the lateral commissure is straight. The hinge line is always easily visible in dorsal view and it produces a hinge angle of around $133^{\circ}$. The apical angle of the shell is rather small and has a mean value of $92^{\circ}$. The beak is rather short and changes from suberect to erect during growth (Figs $9 \mathrm{Ba}-\mathrm{c}, 11 \mathrm{Ca}-\mathrm{c})$. In posterior view (Figs 9Be, 11Ce) the tip of the beak does not extend beyond the surface of the dorsal valve. Beak ridges are clearly visible. The foramen is permesothyrid. The foramen is relatively large in juveniles and remains functional through ontogeny. However, in large adult shells it tends to be reduced but it is never closed by the secondary shell layer. This brachiopod could have been living fixed by means of its pedicle. Disjunct deltidial plates are developed and they appear as medium-sized triangles even in the largest specimens. A pedicle collar can be observed.

The internal morphological characters have been observed in the transverse serial sections (Fig. 10) and they appear representative of the genus Gyrosoria. The minute cardinal process is low, short and ridge-like. Inner socket ridges are strongly developed whereas outer socket ridges are very faint. The crura are thick, oblique, projecting ventrally, and they support a narrow tubelike ring loop. The ventral part of the brachial ring has a concave profile.

Compared with white-chalk G. gracilis from Hallembaye (Fig. 9Da-e, Ef, h) this material from Altembroeck is fairly distinct. The more drop-shaped outline with a ventribiconvex to slightly planoconvex lateral profile, the suberect or erect beak which is never curved, the larger functional permesothyrid foramen, the always clearly visible and well developed triangular deltidial plates, the narrower angle of the hinge line (which is 
Figure 13. Hinge angle to width - a cumulative plot of Gyrosoria lata and G. gracilis clusters. Note that the hinge angle is not width-dependent. The disparatenes of both the Gyrosoria species in this feature is apparent. For explanation see legend.

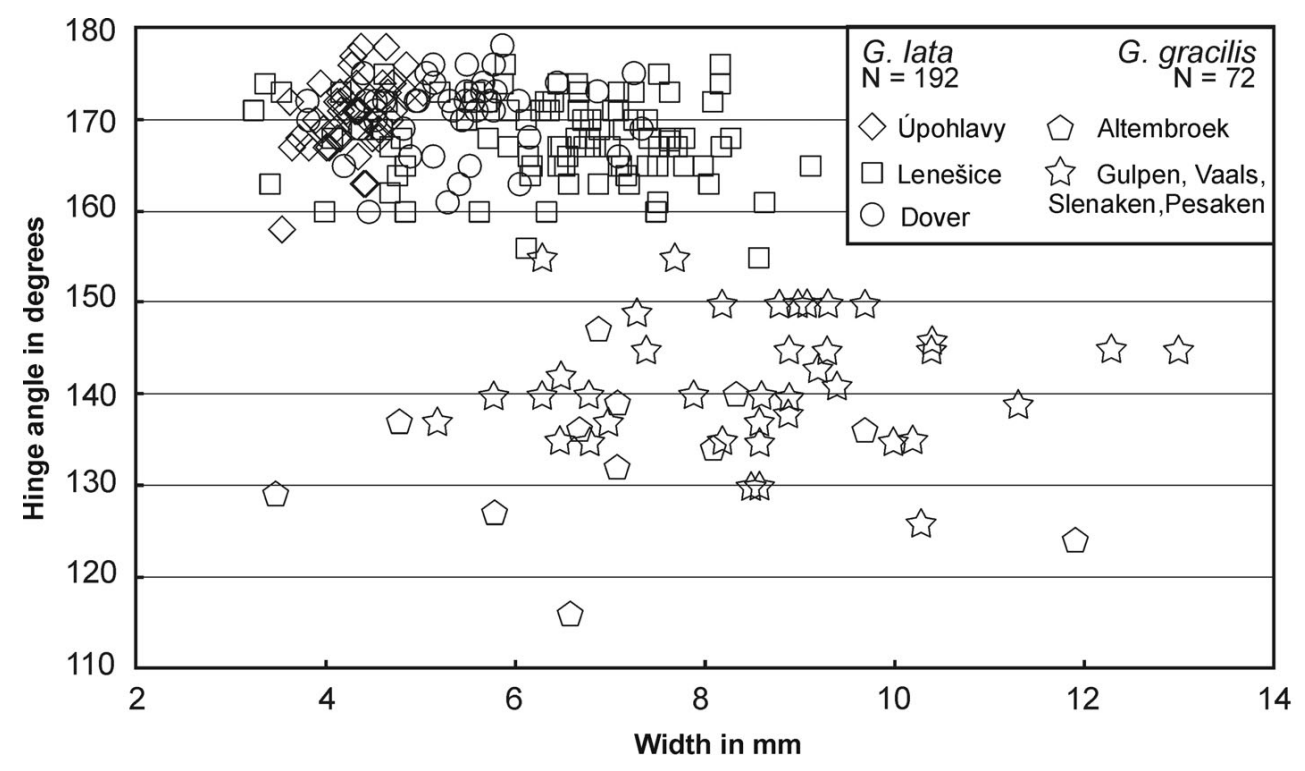

around $155^{\circ}$ in the specimens of $G$. gracilis from Hallembaye) and the narrower apical angle of the beak (which is around $115^{\circ}$ in G. gracilis from Hallembaye) are quite stable characters amongst the specimens investigated. Notwithstanding the low number of specimens studied (25), it could be concluded that Gyrosoria specimens from Altembroeck could be representatives of another species, distinct from $G$. gracilis. Such an option should be carefully considered in connection with the observations made on the material collected from southern Limburg.

Material collected from Slenaken, Pesaken, Gulpen and Vaals (southern Limburg, The Netherlands): This part of the Bosquet collection offers numerous well preserved specimens of Gyrosoria. This collection consists of six distinct samples which, probably, had been collected separately. The notes on the labels are not precise enough to prove this, but the homogeneity of some samples supports the idea. It appears that one sample contains typical G. gracilis similar to the white chalk material described here above whereas other samples consist of numerous shells with very variable morphological characters (Fig. 11A-D, Table 2). The state of preservation of the costellae is variable. Some samples consist of shells with well preserved ornamentation i.e. the specimens with a more typical plano- to concavoconvex lateral profile. But for some other shells it reveals that they were living in a relatively high-energy environment and the ornamentation of the costellae has been abraded. A high-energy environment in some localities is also confirmed by the composition of the associated brachiopod fauna.

Specimens with oval, elongate-oval, transversely oval, slightly drop-shaped, strongly drop-shaped and even with subtriangular outline can be seen. Most of the specimens are ventribiconvex with a very slightly convex dorsal valve (Fig. 11A). Some are more biconvex such as the specimen illustrated (Fig. 11B). Shells with an extremely planoconvex lateral profile can also be seen (Fig. 11D). A slight concavoconvexity of the shell was sometimes developed (Fig. 11C). The beak outline was quite variable, being suberect to erect and even curved in some specimens. The beak can be rather strong (Fig. 11B) or it can be affected by a reduced development (Fig. 11D). The curvature of the beak is also variable. In many specimens the beak is not curved but just erect and in posterior view, its tip does not go beyond the surface of the dorsal valve. But sometimes a slightly curved beak is observed and its tip goes beyond the surface of the dorsal valve. This indicates a possible wide variation in this character which could be correlated with an adaptation to the ecological conditions. Extreme curvature of the beak and reduced foramen can be seen in specimens similar to the material collected in white chalk facies. The foramen is larger when the beak is only suberect or erect.

The material collected from southern Limburg offers numerous specimens with all possible morphological variations for all the considered characters. Extreme morphological forms have been observed. Subcircular, clearly concavoconvex shells with a strong curved beak and reduced foramen are found here in comparison to drop-shaped, clearly planoconvex shells with a very small suberect beak and larger foramen. These forms represent two ways of adaptation to ecological conditions, the first being better adapted to a low-energy environment while the latter represents adaptation to a high-energy environment. Moreover all intermediate forms can also be observed in this material and they illustrate the high phenotypic variability of $G$. gracilis. 
Table 2. Chart of the measurements for selected Gyrosoria gracilis (von Schlotheim) oryctocoenoses. Abbreviations and indexes: L - length, $\mathrm{W}$ - width, $\mathrm{T}$ - thickness, $\beta$ - apical angle, $\gamma$ - hinge-line angle, nbr. cost. - number of costellae.

\begin{tabular}{|c|c|c|c|c|c|c|c|c|c|c|}
\hline Localities & & $\underset{\mathrm{mm}}{\mathrm{L}}$ & $\begin{array}{c}\mathbf{W} \\
\mathbf{m m}\end{array}$ & $\frac{\mathrm{L}}{\mathrm{W}}$ & $\begin{array}{c}\mathrm{T} \\
\mathrm{mm}\end{array}$ & $\frac{T}{W}$ & $\stackrel{\beta}{\circ}_{0}$ & $\gamma$ & $\begin{array}{l}\text { Nbr. } \\
\text { cost. }\end{array}$ & $\frac{\text { Nbr.cost. }}{W}$ \\
\hline \multirow{3}{*}{$\begin{array}{c}\text { Altembroeck, 's Gravenvoeren } \\
\text { Province of Liège, Belgium } \\
\qquad \mathrm{N}=13\end{array}$} & $\min$ & 4.6 & 3.5 & 1.01 & 1.5 & 0.32 & 80 & 116 & 17 & 4.9 \\
\hline & mean & 8.1 & 7.2 & 1.14 & 2.9 & 0.41 & 92 & 133 & 43.1 & 6 \\
\hline & $\max$ & 13.6 & 11.9 & 1.31 & 4.4 & 0.49 & 102 & 147 & 79 & 6.6 \\
\hline \multirow{3}{*}{$\begin{array}{c}\text { Vaals/Slenaken/Pesaken/Gulpen } \\
\text { southern Limburg, } \\
\text { The Netherlands } \\
\text { samples with variable specimens } \\
\mathrm{N}=49 \\
\end{array}$} & $\min$ & 5.1 & 4.3 & 1 & 1.7 & 0.31 & 85 & 126 & 27 & 4.2 \\
\hline & mean & 9 & 8.3 & 1.1 & 3.4 & 0.4 & 98.6 & 140.6 & 46.8 & 5.6 \\
\hline & $\max$ & 14.6 & 13 & 1.2 & 4.9 & 0.51 & 114 & 155 & 75 & 8.2 \\
\hline \multirow{3}{*}{\begin{tabular}{|c|} 
Slenaken/Pesaken, \\
The Netherlands \\
specimens subcircular, concavoconvex \\
with curved beak, typical of chalk \\
facies \\
$N=11$ \\
\end{tabular}} & $\min$ & 6.5 & 5.8 & 1 & 2.6 & 0.3 & 82 & 135 & 30 & 4.2 \\
\hline & mean & 9.5 & 8.9 & 1.1 & 3.6 & 0.4 & 97.9 & 145.6 & 49.5 & 5.6 \\
\hline & $\max$ & 11.7 & 10.4 & 1.2 & 5 & 0.5 & 112 & 155 & 64 & 6.9 \\
\hline \multirow{3}{*}{$\begin{array}{l}\text { Vijlen Member, No localities, } \\
\text { (NHMM coll.) } \\
\text { southern Limburg, } \\
\text { The Netherlands } \\
\mathrm{N}=10\end{array}$} & $\min$ & 8.4 & 7.89 & 1 & 2.95 & 0.34 & 92 & 133 & 40 & 5 \\
\hline & mean & 9.6 & 8.9 & 1.1 & 3.4 & 0.4 & 102.2 & 142.3 & 49.4 & 5.5 \\
\hline & $\max$ & 10.8 & 10.3 & 1.1 & 3.8 & 0.4 & 110 & 155 & 64 & 6.2 \\
\hline \multirow{3}{*}{$\begin{array}{l}\text { All measurements } \\
\qquad N=83\end{array}$} & $\min$ & 4.6 & 3.5 & 0.98 & 1.5 & 0.31 & 80 & 116 & 17 & 4.2 \\
\hline & mean & 9 & 8.3 & 1.09 & 3.3 & 0.4 & 98.5 & 140.6 & 46.8 & 5.6 \\
\hline & $\max$ & 14.6 & 13 & 1.31 & 5 & 0.5 & 115 & 156 & 79 & 8.2 \\
\hline
\end{tabular}

Material collected from the chalk (Vijlen Member) in southern Limburg, The Netherlands: These shells were also taken into account in the measurements presented here (Table 2). These specimens of the Felder collection were collected from the base of the Vijlen member (without precise localities). They are typical specimens, subcircular or drop-shaped, generally with a curved beak. They seem to come from a chalk without glauconite. As they represent the form adapted to a low-energy environment, they are used here as comparison material.

83 specimens of Gyrosoria gracilis were measured and the results are presented in Table 2. The minimal, maximal and mean value of the measurements are given for the different samples investigated and for the whole set of measurements.

For the $\mathrm{L} / \mathrm{W}$ ratio there is no significant distinction between the samples studied. A slight difference is observed with the material from Altembroeck as these specimens appear more elongate. This distinction is mainly due to the fact that many of these shells are juveniles or smaller specimens. For the T/W ratio no significant difference is present between any of the samples studied. The same is also true for the ratio nbr. cost/W. The number of ribs appears a very variable character (Steinich 1965).
These results are quite useful. In fact, except for the specimens from Altembroeck, the results given for both apical angle and angle of the hinge line are similar for the specimens from all the samples studied. Altembroeck specimens have a smaller apical angle and the mean value is also lower for the angle of the hinge line. This lower value for the apical angle as well as for the angle of the hinge line seems linked with the more elongate outline of these shells. This could be more a consequence of the adaptation of this population to a high-energy environment rather than a characteristic allowing the erection of a new species.

Scatter diagrams for morphological parameters are given in Figs 12, 13. These measurements can be compared with the results published by Steinich (1965) which are nearly identical. The mean value for the $\mathrm{L} / \mathrm{W}$ ratio was around 1.1 the mean value for the T/W ratio was around 0.45 and the nbr. cost./W ratio varied between 4 and 9 . The mean value for the angle of hinge line was around $150^{\circ}$. As all specimens from Rügen were collected from white chalk they represent the form of G. gracilis adapted to a relatively low-energy environment i.e. the typical subcircular concavoconvex shell with strongly curved beak and reduced foramen. Only the measurements of the angle of the hinge line give a significant difference with the measurements obtained for the Belgian and 
Dutch specimens adapted to a rougher environment. Considering G. gracilis, the qualitative observations appear more indicative of the variations which are linked with ecological adaptations than the quantitative measurements.

Discussion: A comparison of the specimens obtained from Altembroeck with representatives collected from white chalk deposits such as the material from Hallembaye (Belgium), Rügen (Germany) and Nye Kløv (Denmark), appear distinct enough to consider the erection of a new species as a possible option. These Gyrosoria shells are more drop-shaped and slightly ventribiconvex, their beak is suberect to erect with a relatively large foramen and their costellae seem straighter with a less tuberculated ornamentation. The G. gracilis collected from white chalk deposits are more subcircular and concavoconvex, their beak is strongly curved with a reduced foramen and their costellae are finely tuberculated.

However, the observation of numerous specimens of G. gracilis collected from the Gulp River Valley demonstrated that the morphological characters considered could be highly variable. Specimens, similar in outline to the classical white chalk material, were found together with specimens resembling the material obtained from Altembroeck. Moreover, intermediate forms were also visible in this collection (Fig 11D). It is also demonstrated that ecological variations can determine the behaviour of G. gracilis representatives. The juveniles or young specimens lived attached by means of their pedicle. In a low-energy environment (chalk facies) adult forms became free-lying brachiopods as rapidly as possible. The different outcrops along the Gulp River in southern Limburg represent different types of environment as is suggested by the outline of the specimens when considered sample by sample. In an environment similar to those observed in white chalk facies, the free-lying stage of growth was fully achieved. On the contrary, in a high-energy environment, the adults maintain the use of their pedicle and remained attached to the substrate. In Altembroeck, a relatively rough environment has been suspected, and the Gyrosoria specimens have preserved their juvenile outline and way of life throughout their whole life. These observations lead us to avoid creating of a new species for the specimens from Altembroeck and only one species of Gyrosoria, i.e. G. gracilis, should be considered as accurate for describing the material studied in this part of the paper.

Specimens from white chalk deposits were collected in abundance in many countries for centuries and this rich material has contributed to produce a limited conception of the G. gracilis species. In fact, white chalk deposits are sometimes late Early Maastrichtian but very often early Late Maastrichtian. In such conditions, G. gracilis successfully developed the adaptation to a free-lying way of life. However, this adaptation also reduced the potential for variation in its morphological characters. This induced the traditional conception of a very stable and invariable species of brachi- opod. The G. gracilis living in such conditions were influenced by strong environmental pressure which contributed to reduce the variability of the morphological characters.

For populations coming from older deposits and living in a more energetic environment, a better potential for variation is observed. It is obvious, in such conditions, that $G$. gracilis has been able to develop very variable morphologies as it was usually the case for Gyrosoria representatives such as $G$. lata which was the species at the base of the here-considered lineage.

Stratigraphical range. - Upper Campanian (England) and from early Early Maastrichtian to the latest Late Maastrichtian in other European or Asian localities. The species became extinct at the K/T boundary (Surlyk 1984).

Geographical distribution. - NE Belgium (Hallembaye, Lixhe), The Netherlands (Maastricht area) and in England (Norfolk), Germany (Schleswig-Holstein, Rügen in Vorpommern) and Denmark (Stevns Klint, Møns Klingt, Nye Kløv). Known also from Crimea, Caucasus, Kazakhstan and from Turkmenistan.

\section{Conclusions}

As far as the taxonomical issues have been consolidated, an evolutionary lineage appears with the extremely variable Gyrosoria lata at its base and the far derived, free-lying Gyrosoria gracilis of white-chalk facies at its Upper Maastrichtian top. Abnormal growth within some of the G. lata populations is assumed to be probably influenced by local trophic or climatic conditions. The shape of the shell (mainly the convexity of its valves and curvature of the beak) has been controlled mainly by the character of the sedimentation and closely linked with the turbidity of the environment. Even some G. lata specimens from the Middle Chalk of England have a strongly curved beak and relatively deep ventral valve which suggests a free-lying mode of life in their late ephebic stage. In G. lata this was never the prevailing morphology or strategy, in contrast with G. gracilis of white-chalk facies where the free-lying mode of life for adult specimens seems to be obligatory. Detailed study of populations from Altembroek and the Limburg area showed the influence of the environment on shell development and intraspecific variability.

Stability of the hinge angle as a distinctive character within the genus Gyrosoria has been proved. On the contrary, features such as number of ribs, beak angle, length, width and density of punctae proved to be too variable, too similar to each other or greatly influenced by postmortal biases and therefore inappropriate for distinction between the species. The variability of the internal structures such as loop shape, ascertained in G. lata, proves the necessity for 
multiple sectioning as well as dissection in any brachiopod taxonomic studies.

An ancestor of Gyrosoria is presumed to be closely related to Cruralina. This suggestion is based on both the external and internal morphology of the genera, its variation within the Cruralina genus as well as on stratigraphical ranges of both the genera. The palaeogeographical area of G. lata is extended towards the recent territory of Turkmenistan and its stratigraphical range to the Late Turonian, ?Coniacian. Its wider application as a stratigraphical marker turned out to be indefensible but the species could be still useful in regional stratigraphy.

\section{Acknowledgements}

We are greatly indebted to O. Nekvasilová and M. Košták for their help and critical comments, J. Jagt and S. Čech who contributed to the precision of the stratigraphy of Altembroeck and the BCB respectively as well as to J. Herman who helped us with precise geological settings of localities in southern Belgium. We are also greatfull to reviewers M. Mergl, E. Taddei Ruggiero and M.A. Bitner, to R. Vodrážka and Z. Dvořák who provided us with valuable material from their collections, R. Winkler (SNSD, Dresden), S. Long (NHM, London), E. Steurbaut (IRScNB, Brussels), L. Neep (BGS, Keyworth), H. Summesberger (NHMW, Wien) and S. Štamberk (MEB, Hradec Králové) for their help and access to the collections and to the Lafarge Cement a.s. company for long-term permission which allowed us to collect material within the Úpohlavy quarry. We want to express our thanks to W. Miseur and J. Cilis too, as they took the majority of high professional quality SEM and non-SEM photos and to M. Mazuch who provided us with help in taking SEM photos in Prague. This research has been undertaken as a part of the GAČR project No. 205/06/0842 and a grant project of the Ministry of Culture of the Czech Republic No. DE06P04OMG009 MK. The G. gracilis part of this paper is contribution No. 18 of the "Vijlen Werkgroep", Maastricht. Study of the material stored in the NHM collections was funded by SYNTHESYS Project which is financed by the European Community Research Infrastructure Action under the FP6 "Structuring the European Research Area” Programme.

\section{References}

AGER, D.V. 1965. Serial grinding techniques, 212-224. In KUMMEL, B. \& RAUP, D. (eds) Handbook of paleontological techniques. xiii +852 pp. Freeman and Co., San Francisco \& London.

BARROIS, C. 1876. Recherches sur le terrain Crétacé Supérieur de l'Angleterre et de l'Irlande. 232 pp. Société Géologique du Nord, Lille.

BOSQUET, J. 1860. Versteeningen uit het Limburgsche Krijt, 361-418. In STARING, W.C.H. (ed.) De Bodem van Nederland. De zamenstelling en het ontstaan der gronden in Nederland ten behoeve van het algemeen beschreven, Tweede deel. A.C. Kruseman, Haarlem.
BUCH, L. VON 1835. Über Terebrateln. Abhandlungen der Königlichen Akademie der Wissenschaften zu Berlin 21, 21-144.

CHRISTENSEN, W.K. 1999. Upper Campanian and Lower Maastrichtian belemnites from the Mons Basin, Belgium. Bulletin de l'Institut royal des Sciences naturelles de Belgique, Sciences de la Terre 69, 97-131.

CHRISTENSEN, W.K. \& SCHMIDT, F. 1987. The belemnites from the Vaals Formation from the CPL quarry at Hallembaye in Belgium. Taxonomy, biometry and biostratigraphy. Geologisches Jahrbuch A 94, 3-37.

COOPER, G.A. 1973. Fossil and Recent Cancellothyridacea (Brachiopoda). Tohoku University Science Report, $2^{\text {nd }}$ Ser. (Geol.), Special Volume 6 (Hatai Memorial Volume), 371-390.

CROFT, W.N. 1950. A parallel grinding instrument for the investigation of fossils by serial sections. Journal of Paleontology 24(6), 693-698.

ČECH, S. 1995. Korelace turonských sedimentů východočeské křídy. Zprávy o geologických výzkumech v roce 1994, 23-24.

ČECH, S., KLEIN, V., KŘİŽ, J. \& VALEČKA, J. 1980. Revision of the Upper Cretaceous stratigraphy of the Bohemian Cretaceous Basin. Věstník Ústředního ústavu geologického 55, 227-296.

DAVIDSON, T. 1852-1855. A monograph of the British Fossil Brachiopoda. Part 2. 117 pp. The Palaeontographical Society, London.

DHONDT, A.V. \& JAGT, J.W.M. 1987. Bivalvia uit de kalksteen van Vijlen in Hallembaye (België). Grondboor en Hamer 41(3/4), 78-90.

ETHERIDGE, R. 1881. Brachiopoda, 147-148. In PENNING, W.H. \& JUKES-BROWNE, B.A. The geology of the neighbourhood of Cambridge 184 pp. Memoirs of the Geological Survey, London.

Felder, P.J., Felder, W.M. \& BRomley, R.G. 1980. The type area of the Maastrichtian Stage, 79-88. In BIRKELUND, T. \& BROMLEY, R.G. (eds) Upper Cretaceous and Danian of NW Europe, Guide to Excursion 069 A. $26^{e}$ Congrès Géologique International. Paris.

FRIČ, A. 1889. Studien im Gebiete der Böhmischen Kreideformation; Palaeontologische Untersuchungen der einzelnen Schichten; IV. Die Teplitzer Schichten. Archiv der naturwissenschaftiche Landesdurchforschung von Böhmen 7(2), 1-120.

GASPARD, D. 1997. Distribution and recognition of phases in Aptian-Turonian (Cretaceous) brachiopod development in NW Europe. Geologica Carpathica 48(3), 145-161.

GEINITZ, H.B. 1873. Das Elbthalgebirge in Sachsen. 2. Der mittlere und obere Quader, II. Brachiopoden und Pelecypoden, 23-72. Theodor Fischer, Cassel.

HAGENOW, F. VON 1842. Monographie der Rügen'schen KreideVersteinerungen, III. Abtheilung: Mollusken. Neues Jahrbuch für Mineralogie, Geognosie, Geologie und Petrefactenkunde 5, 528-575.

THE INTERNATIONAL TRUST FOR ZOOLOGICAL NOMENCLATURE (eds) 1999. International Code of Zoological Nomenclature. Fourth Edition. 306 pp. The Natural History Museum, London.

JAGT, J.W.M., DECKERS, M., DHONDT, A.V., DORTANGS, R.V., FElder, P.J., Felder, W.M., Keutgen, N., Kuypers, M., Michels, G., Reynders, J., SimON, E., VAN DER HAM, R., VAN KNIPPENBERG, P. \& VAN NEER, R. 1995. Preliminary re- 
port of field work at Altembroeck (NE Belgium, Early Maastrichtian). Ministère des Affaires économiques - Administration des mines - Service géologique de Belgique - Professional Paper 1995/1(276), 1-20.

JAGT, J.W.M. \& MiCHELS, G.P.H. 1990. Additional note on the echinoid genus Cyclaster from the Late Maastrichtian of northeastern Belgium. Geologie en Mijnbouw 69, 179-185.

JOHANSEN, M.B. 1987. Brachiopods from the MaastrichtianDanian boundary sequence at Nye Kløv, Jylland, Denmark. Fossils and Strata 20,1-57.

JOHANSEN, M.B. 1988. Brachiopod extinctions in the Upper Cretaceous to lowermost Tertiary Chalk of Northwest Europe. Revista Española de Paleontologia, $n^{\circ}$ extraordinario, 41-56.

JOHANSEN, M.B. 1989a. Adaptive radiation, survival and extinction of Brachiopods in the Northwest European Upper Cretaceous - Lower Paleocene Chalk. Palaeogeography, Palaeoclimatology, Palaeoecology 74, 147-204.

DOI 10.1016/0031-0182(89)90060-6

JOHANSEN, M.B. 1989b. Background extinction and mass extinction of the brachiopods from the chalk of Northwest Europe. Palaios 5(4), 243-250. DOI 10.2307/3514772

JOHANSEN, M.B. \& SURLYK, F. 1990. Brachiopods and the stratigraphy of the Upper Campanian and Lower Maastrichtian Chalk of Norfolk, England. Palaeontology 33(4), 823-872.

KATZ, J.I. 1974. Tip Brachiopoda - brachiopody, 240-275. In BLANK, M.J., KRYMGOLC, G.J., NAIDIN, D.P. \& SAVCHINSKAYA, O.V. (eds) Atlas verchnemelovoi fauny Donbassa. Nedra.

KeUtGEN, N. 1996. Biostratigraphie, Paläoökologie und Invertebratenfauna des Untermaastricht von Aachen (Westdeutschland) und angrenzenden Gebieten (Südostniederlande, Nordostbelgien). iv + 123 pp. Shaker Verlag, Aachen.

KeUtGEN, N. 1997. Belemnella (Belemnella) cf. praearkhangelskii Naidin, 1964 from the Vijlen Member at Altembroeck (NE Belgium, Early Maastrichtian). Geologie en Mijnbouw 75, 341-347.

Keutgen, N., JAGT, J.W.M., FELDER, P.J. \& JAGT-YAZYKovA, E.A. In press. Stratigraphy of the upper Vijlen Member (Gulpen Formation; Maastrichtian) in northeast Belgium, the southeast Netherlands and the Aachen area (Germany), with special reference to belemnitellid cephalopods. Netherlands Journal of Geosciences.

Keutgen, N. \& VAN DER TUUK, L.A. 1991. Belemnites from the Lower Maastrichtian of Limburg, Aachen and Liège. Mededelingen van de Rijks geologische dienst 44(4), 1-29.

KrutSKÝ, N., VÁNĚ, M., HolÁ, A. \& HerCogová, J. 1975. Turon a coniak v dolním Poohří. Sborník geologických věd, Geologie 27, 99-137.

LEE, D.E., MACKINNON, D.I., SMIRNOVA, T. N., BAKER, P.G., YU-GAN, J. \& DONG-LI, S. 2006. Terebratulida, 1965-2255. In KAESLER, R.L. (ed.) Treatise on invertebrate paleontology, Part H, Brachiopoda 5 (revised). Geological Society of America \& The University of Kansas Press, Boulder \& Lawrence.

LinNAEUS, C. 1758. Systema naturae, $10^{\text {th }}$ ed. Vol. 1.824 pp. Laurentii Salvii, Stockholm.

MACÁK, F. 1963. Koprolitová vrstvička a koštické plošky v křídě ohárecké oblasti. Časopis pro mineralogii a geologii 8(4), 380-382.
MANTELl, G.A. 1822. Fossils of the South Downs or illustrations of the Geology of Sussex. 327 pp. London.

MORTIMORE, R.N. 1986. Stratigraphy of the Upper Cretaceous White Chalk of Sussex. Proceedings of the Geologists' Association 97(2), 97-139.

NAIDIN, D.P. 1964. Upper Cretaceous Belemnitella and Belemnella from Russian Platform and some adjacent regions. Byulleten Moskovskogo obshchestva ispytatelei prirody, Otdel geologicheskii 39, 85-87.

NeCHRIKOVA, N.I. 1982. Brachiopoda. In Atlas of the Upper Cretaceous faunas from the Peri-Caspian Depression. Trudy Paleontologicheskogo instituta 187, 26-49.

NEKVASILOVÁ, O. 1978. Cancellothyridacea (Brachiopoda) from the Lower Cretaceous of Stramberk (Czechoslovakia). Časopis pro mineralogii a geologii 23(2), 171-182.

NILSSON, S. 1827. Petrificata suecana. 39 pp. Lund.

OrbignY, A. D' 1845. Mollusques, Système crétacé 2(3), 489-498. In Murchison, R.I., Verneuil, E. DE \& KeYSERLING, A. de (eds) Géologie de la Russie d'Europe et des montagnes de l'Oural, Paléontologie. Bertrand, Paris.

ORBIGnY, A. D' 1847. Paléontologie française. Description des mollusques et rayonnés fossiles. Terrains crétacés. 4 Brachiopodes. 390 pp. Victor Masson, Paris.

ORBIGNY, A. D' 1849. Paléontologie française. Terrains crétacés. 4 - Brachiopodes. Atlas. Pls. 490-599. Victor Masson, Paris.

ORBIGNY, A. D' 1852. Prodrome de Paleontologie stratigraphique universelle des animaux mollusques et rayonnés, Vol. 3, Table alphabétique et synonymique. 189 pp. Victor Masson, Paris.

OWEN, E. 2002. Brachiopods, 77-98. In SMITH, B. \& BATTEN, J. (eds) Fossils of the Chalk, Second edition, revised and enlarged. The Palaeontological Association, London.

PETTITT, N.E. 1950. A monograph on the Rhynchonellidae of the British Chalk, Part I. 26 pp. Palaeontographical Society, London.

PoSSELT, J.H. 1894. Brachiopoderne i den danske Kridtformation. Danmarks geologiske Undersøgelser 2(4), 1-59.

QuenstedT, F.A. 1868-1871. Petrefactenkunde Deutschlands. Zweiter Band, Brachiopoden. 748 pp., 25 pls. Fues's Verlag, Leipzig.

REUSS, A. E. 1846. Die Versteinerungen der Böhmischen Kreideformation. Zweite Abtheilung. 148 pp. Stuttgart.

RICHARDSON, J. 1997. Ecology of articulated brachiopods, 441-472. In KAESLER, R.L. (ed.) Treatise on invertebrate paleontology, Part H, Brachiopoda 2 (revised). Geological Society of America \& The University of Kansas Press, Boulder \& Lawrence.

RoBASZYNSKI, F., DHONDT, A.V. \& JAGT, W.M. 2001. Cretaceous lithostratigraphic units (Belgium). Geologica Belgica 4, 121-134.

ROEMER, F.A. 1841. Die Versteinerungen des norddeutschen Kreidegebirges. 145 pp. Hahn'schen Hofbuchhandlung, Hannover.

Rowe, M. 1901. The Zones of the White Chalk of the English Coast, II: Dorset. Proceedings of the Geologists' Association 17, 1-76.

SAHNI, M.R. 1925. Morphology and zonal distribution of some Chalk Terebratulids. The Annals and Magazine of Natural History $15(9), 353-385$. 
SANDY, M.R. 1986. Brachiopod systematics and the transverse serial sectioning method: some recommendations for this technique and clarification of a taxonomic problem assisted by this method, 209-218. In RACHEBOEUF, P.R. \& EMIG, C. (eds) Les Brachiopodes fossiles et actuels. Biostratigraphie du Paléozoïque 4. Université de Bretagne occidentale, Brest.

SCHLOENBACH, U. 1866. Beiträge zur Paläontologie der Jura- und Kreide-Formation im nordwestlichen Deutschland. Palaeontographica 13, 265-332.

SCHLOENBACH, U. 1868. Kleine paläontologische Mittheilungen, 2. Folge (III. Die Brachiopoden der böhmischen Kreide). Jahrbuch der kaiserlich-königlichen geologischen Reichsanstalt 18(1), 139-166.

SCHLOTHEIM, E.F. VON 1813. Beiträge zur Naturgeschichte der Versteinerungen in geognostischer Hinsicht. Leonhard's Taschenbuch für die gesammte Mineralogie 7(1), 3-134.

SCHUMANN, D. 1973. Mesodermale Endoskelette terebratulider Brachiopoden. I. Paläontologische Zeitschrift 47, 77-103.

SimON, E. 1993. Possible presence of Cretirhynchia undulata (Pusch, 1837) in de Vijlen Chalk (Upper Maastrichtian) from Hallembaye (Belgium). Bulletin de l'Institut royal des Sciences naturelles de Belgique, Sciences de la Terre 63, 73-98.

SimON, E. 2005. New Lower Maastrichtian brachiopods (Gulpen Formation, Vijlen Member) from southern Limburg (The Netherlands). Bulletin de l'Institut royal des Sciences naturelles de Belgique, Sciences de la Terre 75, 127-165.

SIMON, E. \& OWEN, E.F. 2001. A first step in the revision of the genus Cretirhynchia Pettitt, 1950. Bulletin de l'Institut royal des Sciences naturelles de Belgique, Sciences de la Terre 71, 53-118.

SMIRNOVA, T.N. 1966. K sistematike rannemelovych terebratulid podsemeistva Cancellothyrinae. Paleontologicheskii Zhurnal 3, 31-41.

SMIRNOVA, T.N. 1972. Rannemelovye brachiopody Kryma i severnogo Kavkaza. 143 pp. Nauka, Moscow.

SOWERBY, J. \& SOWERBY, J. DE C. 1829. The mineral conchology of Great Britain; or coloured figures and descriptions of those remains of testaceous animals or shells, which have been preserved at various times and depths in the earth, 6. $249 \mathrm{pp}$. London.

STEINICH, G. 1963. Fossile Spicula der Brachiopoden der Rügener Schreibkreide. Geologie 12(5), 604-610.

STEINICH, G. 1965. Die artikulaten Brachiopoden der Rügener Schreibkreide (Unter - Maastricht). Paläontologische Abhandlungen, Abteilung A, Paläozoologie 2, 1-220.

STERNBERG, R.M. \& BELDING, H.F. 1942. Dry-peel technique. Journal of Paleontology 16, 135-136.

SURLYK, F. 1972. Morphological adaptations and population structures of the Danish Chalk brachiopods (Maastrichtian, Upper Cretaceous). Det Kongelige Danske Videnskabernes Selskab, Biologiske Skrifter 19(2), 1-57.

SURLYK, G. 1980. Upper Cretaceous and Danian outcrops in Scania and East Denmark, 21-48. In BIRKELUND, T. \& BROMLEY, R.G. (eds) Upper Cretaceous and Danian of NW Europe, Guide to Excursion 069 A. $26^{e}$ Congrès Géologique International. Paris.

SURLYK, F. 1982. Brachiopods from the Campanian-Maastrichtian boundary sequence, Kronsmoor (NW Germany). Geologisches Jahrbuch A 61, 259-277.
SURLYK, F. 1984. The Maastrichtian Stage in NW Europe, and its brachiopod zonation. Bulletin of the Geological Society of Denmark 33, 217-223.

SURLYK, F. \& JOHANSEN, M.B. 1984. End-Cretaceous brachiopod extinctions in the chalk of Denmark. Science 223, 1174-1177. DOI 10.1126/science.223.4641.1174

TARKOWSKI, R. 1991. Stratygrafia, makroskamieniałości i paleogeografia utworów górnej kredy niecki opolskiej. Zieszyty naukowe Akademii Górnicko-Hutnieczkej, Geologia 51, 1-156.

TARKOWSKI, R. 1996. Inoceramid biostratigraphy in the Turonian of the Opole Trough (southwestern Poland). Mitteilungen aus dem Geologisch-Paläontologischen Institut der Universität Hamburg 77, 489-501.

Titova, M.V. 1959. Brachiopoda, 221-244. In Moskvin, M.M. (ed.) Atlas verchnemelovoy fauny severnogo Kavkaza i Kryma. Gostoptechizdat, Moscow.

TitovA, M.V. 1977. Pozdnemelovye Cancellothyrididae (Brachiopoda) Turkmenii. Paleontologicheskii Zhurnal 4, 73-85.

TitovA, M.V. 1992. Upper Cretaceous brachiopods from southern USSR, 137-171. In ZONOVA, T.D. et al. (eds) Atlas rukovodiashchikh Grupp Fauny Mezozoia Iuga i Vostoka SSSR. Moscow. [in Russian]

VÁNĚ, M. 1964. Lenešická cihelna, 133-134. In Krutský, N. (ed.) Sborník kXV. sjezdu Československé společnosti pro mineralogii a geologii s exkurzním průvodcem. 264 pp. Československá společnost pro mineralogii a geologii, Teplice.

VODRÁŽKA, R. 2009. A new method for the extraction of macrofossils from calcareous rocks using sulphuric acid. Palaeontology 52(1), 187-192.

DO] $10.1111 / \mathrm{j} .1475-4983.2008 .00829 . x$

Wiese, F., ČECH, S., EKRT, B., KošŤÁK, M., MAZUCH, M. \& VOIGT, S. 2004. The Upper Turonian of the Bohemian Cretaceous Basin (Czech Republic) exemplified by the Úpohlavy working quarry: integrated stratigraphy and palaeoceanography of gateway to the Tethys. Cretaceous Research 25, 329-352. DO] 10.1016/j.cretres.2004.01.003

WILliams, A., CARLSON, S.J. \& BRUNTON, C.H.C. 2000. Brachiopod classification, 1-27. In KAESLER, R.L. (ed.) Treatise on invertebrate paleontology, Part H, Brachiopoda 2 (revised). Geological Society of America \& The University of Kansas Press, Boulder \& Lawrence.

Williams, A., Carlson, S.J., Brunton, C.H.C., Holmer, L.E. \& POPOV, L. 1996. A supra-ordinal classification of the Brachiopoda. Philosophical Transactions of the Royal Society of London B351(4), 1171-1193.

DO] 10.1098/rstb.1996.0101

Williams, A., JAMES, M.A., EMIG, C.C., MACKAY, S. \& RHODES, M.C. 1997. Anatomy, 7-188. In KAESLER, R.L. (ed.) Treatise on invertebrate paleontology, Part H, Brachiopoda 1 (revised). Geological Society of America \& The University of Kansas Press, Boulder \& Lawrence.

ZAHÁLKA, Č. 1918. Východočeský útvar kř́dový. 80 pp. Roudnice nad Labem.

ŽíTT, J. \& VODRÁŽKA, R. 2008. New data on Late Turonian crinoids from the Bohemian Cretaceous Basin, Czech Republic. Bulletin of Geosciences 83(3), 311-326.

DOI 10.3140/bull.geosci.2008.03.311 